\title{
EFEITO DAS PLANTAÇÕES FLORESTAIS (Eucalyptus sp.) SOBRE A DINÂMICA DE NUTRIENTES EM REGIÃO DE CERRADO DO ESTADO DE SÃO PAULO
}

SIMONE APARECIDA VIEIRA

Engenheira Agrônoma

Orientador: Prof. Dr. FÁBIO POGGIANI

Dissertação apresentada à Escola Superior de Agricultura "Luiz de Queiroz", Universidade de São Paulo, para obtenção do título de Mestre em Ciências, Área de Concentração: Ciências Florestais

PIRACICABA

Estado de São Paulo - Brasil

Junho - 1998 
Dados Internacionais de Catalogação na Publicação (CIP)

DIVISĀO DE BIBLIOTECA E DOCUMENTAÇĀO - Campus "Luiz de Queiroz"/USP

Vieira, Simone Aparecida

Efeito das plantaçōes florestais (Eucalyptus sp.) sobre a dinâmica de nutrientes em região de cerrado do Estado de São Paulo" / Simone Aparecida Vieira. - - Piracicaba, 1998.

73 p. : il.

Dissertação (mestrado) - Escola Superior de Agricultura Luiz de Queiroz, 1998. Bibliografia.

CICLAGEA DE MURTOUE

1. 2. Eucalipto 3. Serapilheira de cerrado I. Titulo

CDD 634.9734 
Ofereşo a minha familia pelo apóio recebido

Dedico a Beto, Pedro e Ana Luiza pelo tempo roubado.

"PARA SER GRANDE, sê inteiro: nada

Tou exsgera ou exclui.

Sê todo om oada coisa. Pōo quanto ós

No mínimo que fazes.

Assim om cada lago a lua toda

Brilha, porque alta vive"

(Fornando Passoa) 


\section{AGRADECIMENTOS}

- Ao Prof. Fábio Poggiani, pela orientação no trabalho desenvolvido.

- Ao Centro de Apoio a pesquisa do Estado de São Paulo - CAPES pela bolsa concedida

- A Companhia Suzano de Papel e Celulose pela concessão de parte da área de estudo.

- Ao Prof. Stape, responsável pelo Horto Experimental de Itatinga, por todo o apoio logístico oferecido assim como ao Eng ${ }^{\circ}$ Rildo Moreira e à todos os funcionários do Horto.

- Aos professores e funcionários do Departamento de Ciências Florestais e do IPEF, pela ajuda dispensada.

- A equipe do Laboratório de Ecologia Aplicada, do Departamento de Ciências Florestais e do Laboratório do Departamento de Ciências do Solo, da ESALQ.

- Ao prof. João L. Batista, pelo axílio no planejamento da pesquisa e em sua análise.

- A todos os colegas da pós-graduação, em especial a Eng ${ }^{a}$ Agrônoma Carla D. Câmara e ao Eng ${ }^{\circ}$ Florestal Lúcio V. de Araújo, pela grande ajuda e amizade.

- A todos que me auxiliaram nesta caminhada. 
LISTA DE FIGURAS

LISTA DE TABELAS

RESUMO

SUMMARY

1. INTRODUÇÃO.

2. CONSIDERAÇÕES SOBRE O CERRADO E A CICLAGEM 3

DE NUTRIENTES.

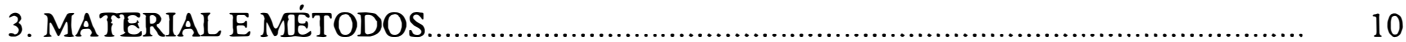

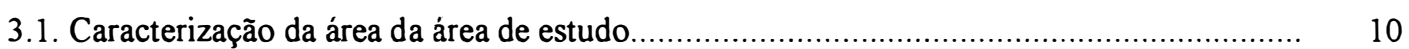

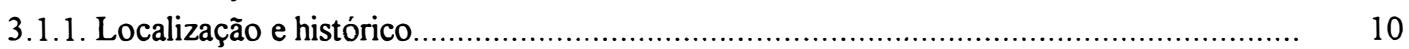

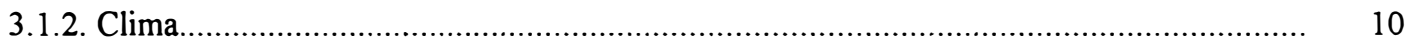

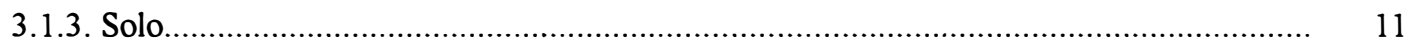

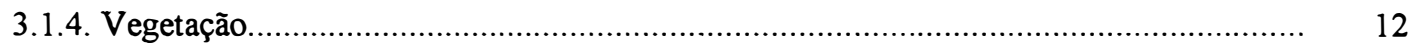

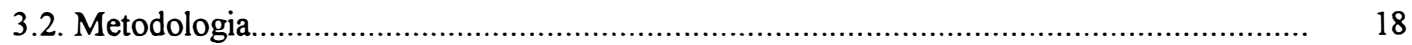

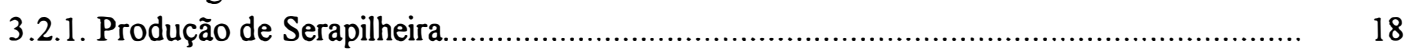

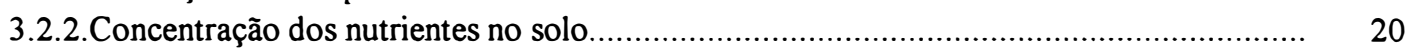

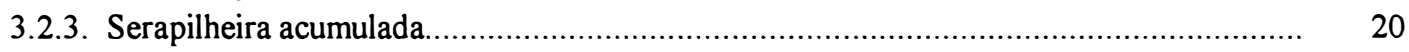

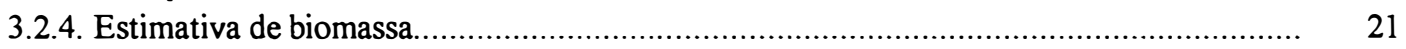

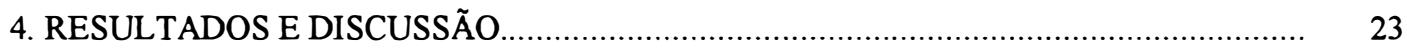

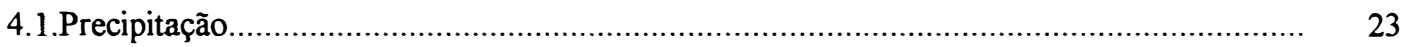

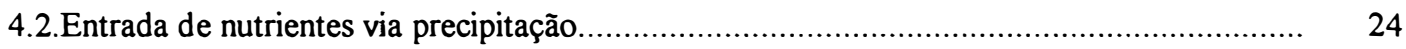

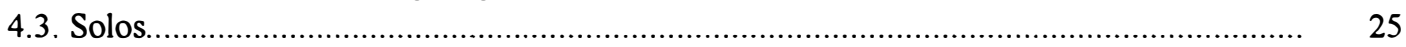

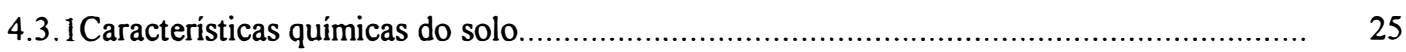

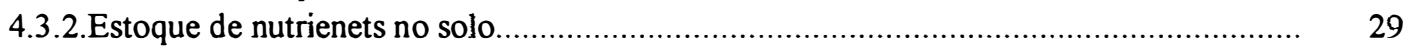

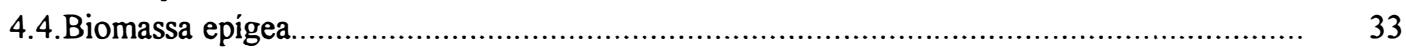

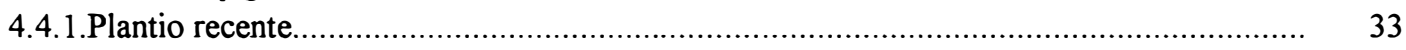

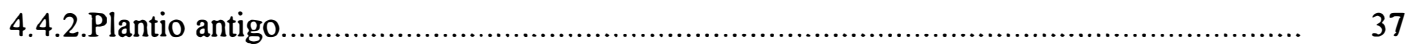

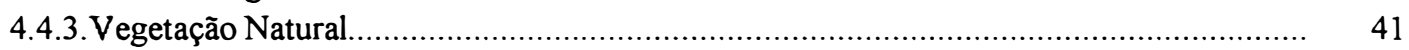

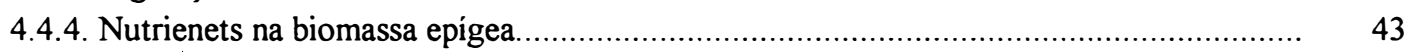

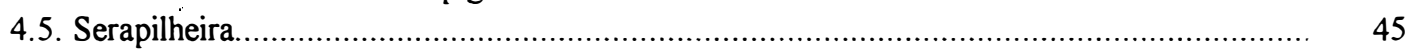

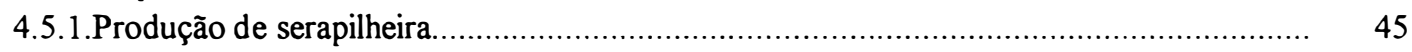

4.5.2. Nutrientes depositados transferidos as solo via serapilheira....................................... 51

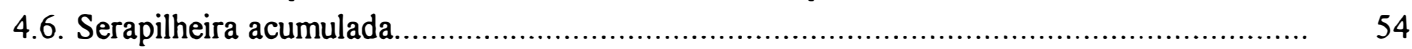

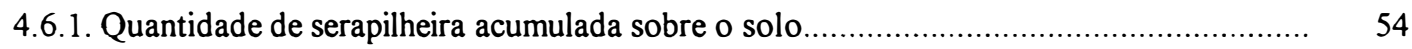

4.6.2. Nutrientes armazenados na serapilheira acumulada ..................................................... 55

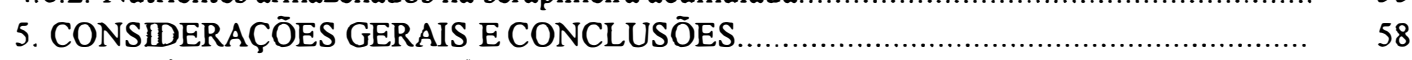

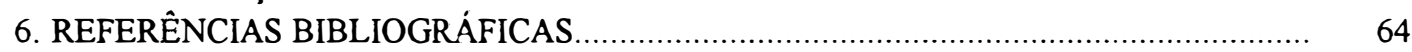


Distribuição da área de Cerrado no Brasil (Fonte: IBGE, 1993)............................. 4

Categorias fisionômicas de cerrado.

Vista aérea do Horto de Itatinga.

Vista geral da área de vegetação natural da Estação Experimental de Itatinga, SP.

Vista geral do plantio de Eucalyptus saligna.

Vista geral do plantio de Eucalyptus grandis.

Estoque de matéria orgânica no solo, até $60 \mathrm{~cm}$ de profundidade, em área sob vegetação natural, plantio de $E$. saligna (plantio antigo),

E. grandis (plantio recente)...

Estoque de nutrientes (N, P, K, Ca e Mg) no solo até $60 \mathrm{~cm}$ de profundidade em área sob plantio de $E$. saligna (plantio antigo), E. grandis (plantio recente) e vegetação natural em região de cerrado do Estado de São Paulo.

Incremento médio anual de biomassa em plantio de $E$. saligna (plantio antigo) e E. grandis (plantio recente).

Produção anual de serapilheira em área de vegetação natural (cerradão), plantio de Eucalyptus grandis (plantio recente) e plantio de Eucalyptus saligna (plantio antigo).

13 Produção mensal de serapilheira em $\mathrm{Kg}$ /ha em área de vegetação natural, plantio de Eucalyptus saligna (plantio antigo) e plantio de Eucalyptus grandis (plantio recente), no municipio de Itatinga, (SP), durante o período de agosto de 1996 e julho de 1997.

Distribuição da biomassa na serapilheira, tronco e folhas nos ecossistemas de vegetação natural, plantio de $E$. saligna e $E$. granudis.

Conteúdo dos macronutrienets no solo, na serapilheira, no tronco e nas folhas de um plantio de $E$. grandis (plantio recente), em região de cerrado do Estado de São Paulo.

Conteúdo dos macronutrientes no solo, na serapilheira, no tronco e nas folhas de uma área de plantio de $E$. saligna (plantio antigo), na região de cerrado do Estado de São Paulo 


\section{TABELAS}

Páginas

1 Lista das principais espécies presentes em 1997 na área de vegetação natural em regeneração do Horto de Itatinga

2 Identificação da procedência das amostras formadoras de cada amostra composta de serapilheira depositada

3 Características químicas do solo sobre área de vegetação natural, plantio de Eucalyptus grandis (plantio recente) e Eucalyptus saligna (plantio antigo)

4 Nutrientes estocados no solo sob vegetação natural, plantio de $E$. saligna (plantio antigo), E. grandis (plantio recente).

5 Biomassa epígea de um plantio de E.grandis de 6 anos em t.ha-1 e a $\%$ presente em cada um dos compartimentos.

6 Biomassa epígea de um plantio de $E$. saligna de 16 anos em t.ha-1 e a

$\%$ presente em cada um dos compartimentos.

7 Biomassa epígea de uma área de vegetação natural em regeneração (cerradão)

8 Biomassa estocada na vegetação de três ecossistemas (vegetação natural, Eucalyptus grandis com 6 anos e Eucalypus saligna com 16 anos) no Horto de Itatinga, S.P., em t.ha-1

9 Teor médio de nutrientes nas folhas, galhos e troncos da vegetação de áreas de vegetação natural, $E$. saligna (plantio antigo) e $E$. grandis (plantio recente) na região de cerrado do Estado de São Paulo

10 Estoque de nutrientes na biomassa epígea de vegetação natutral, $E$. saligna (plantio antigo) e E. grandis (plantio recente) na região de cerrado do Estado de São Paulo

11 Distribuição da produção de serapilheira em área de vegetação natural, plantio de Eucalyptus saligna (plantio antigo) e plantio de Eucalyptus grandis (plantio recente), no município de Itatinga, (SP)

12 Concentração de nutrientes na serapilheira deposistada na área de vegetação natural, no talhão de $E$. saligna (plantio antigo) e de $E$. grandis (plantio recente)

13 Quantidade de serapilheira produzida em área de vegetação natural, plantio de E. saligna (16 anos) e plantio de E. grandis (6 anos) em região de cerrado do Estado de São Paulo...

14 Estoque de serapilheira acumulada sobre o solo nos ecossistemas de vegetação natural, Eucalypus saligna com 16 anos e Eucalyptus grandis com 6 anos. 
15 Concentração nutrientes estocados na serapilheira depositada sobre o . solo em área de vegetação natural, plantio de Eucalyptus saligna (antigo) e plantio de Eucalyptus grandis (recente) em g.Kg-1

16 Nutrientes estocados na serapilheira depositada sobre o solo em uma área de vegetação natural, um plantio de Eucalyptus saligna (antigo), e em um plantio de Eucalyptus grandis (recente) em Kg.ha-1 


\title{
EFEITO DAS PLANTAÇÕES FLORESTAIS (Eucalyptus sp.) SOBRE A DINÂMICA DE NUTRIENTES EM REGIÃO DE CERRADO DO ESTADO DE SÃO PAULO
}

\author{
Autora: SIMONE APARECIDA VIEIRA \\ Orientador: Prof. Dr. FÁBIO POGGIANI
}

\section{RESUMO}

Visando identificar os possíveis efeitos das plantações homogêneas de Eucalyptus spp sobre a dinâmica de nutrientes em áreas na região de cerrado do Estado de São Paulo (Estação Experimental de Itatinga), foi estudada a produção mensal de serapilheira da vegetação natural (cerradão em fase de recomposição), em um plantio de Eucalyptus saligna com 16 anos de idade (na sétima rotação) e em um plantio de Eucalyptus grandis com seis anos de idade e adubado. A produção anual de serapilheira entre o período de agosto de 96 e julho de 1997 foi de 7,3 t.ha $^{-1}$ para o plantio de $E$. grandis, 4,8 tha ${ }^{-1}$ para o plantio de E. saligna e 5,9 t.ha $^{-1}$ para a vegetação natural. A vegetação natural apresentou uma maior de produção de serapilheira entre os meses de junho a novembro. No plantio de E. saligna o pico de produção de serapilheira se concentrou nos meses de novembro-dezembro, sendo que nos demais meses do ano a produção se mostrou constante. O plantio de $E$. grandis também apresentou uma queda acentuada de serapilheira nos meses de novembro-dezembro, ocorrendo um segundo pico de menor intensidade nos meses de fevereiro-março. A quantidade de nutrientes depositados anualmente, via serapilheira, pela vegetação natural foi $150 \mathrm{Kg} \cdot \mathrm{ha}^{-1} \cdot \mathrm{ano}^{-1} \mathrm{de}$ 
N, 6,7 Kg.ha ${ }^{-1} \cdot$ ano $^{-1}$ de P, 29,1 Kg.ha ${ }^{-1} \cdot$ ano $^{-1}$ de K, 91,0 Kg.ha- ${ }^{-1} \cdot$ ano $^{-1}$ de Ca e 23,2

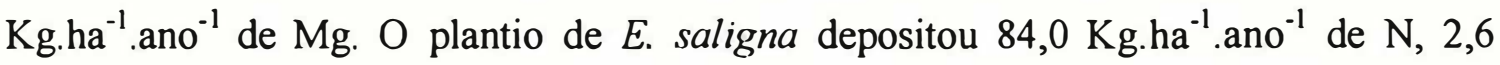

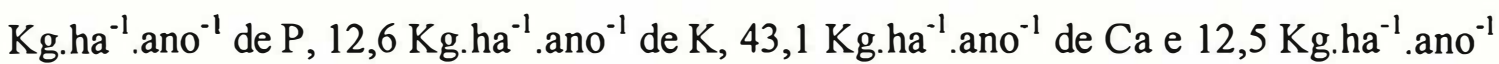
de $\mathrm{Mg}$. O plantio de E. grandis retomou ao solo 93,3 Kg.ha- ${ }^{-1} \cdot \mathrm{ano}^{-1}$ de $\mathrm{N}, 3,9 \mathrm{Kg} \cdot \mathrm{ha}^{-}$ ${ }^{1}$.ano ${ }^{-1}$ de P, 21,7 Kg.ha ${ }^{-1}$.ano ${ }^{-1}$ de K, 54,2 Kg.ha ${ }^{-1}$.ano ${ }^{-1}$ de Ca e 17,5 Kg.ha ${ }^{-1}$.ano ${ }^{-1}$ de $\mathrm{Mg}$.

O estoque de nutrientes no solo até $60 \mathrm{~cm}$ de profundidade na área de vegetação natural foi de $265 \mathrm{Kg} \mathrm{ha}^{-1}$ de N, 20,5 Kg.ha ${ }^{-1}$ de P, 98,7 Kg.ha ${ }^{-1}$ de K, 370,8 Kg.ha ${ }^{-1}$ de Ca e $176,2 \mathrm{Kg} \cdot \mathrm{ha}^{-1} \mathrm{de} \mathrm{Mg}$, para a área sob plantio de E. saligna (plantio antigo) foi de 32,9 Kg.ha ${ }^{-1}$ de N, 14,3 Kg.ha ${ }^{-1}$ de P, 66,5 Kg.ha ${ }^{-1}$ de K, 370,7 Kg.ha ${ }^{-1}$ de Ca e 182,4 Kg.ha ${ }^{-1}$ de $\mathrm{Mg}$ e para a área sob plantio de E. grandis (plantio recente) o estoque foi de 197,5 Kg.ha ${ }^{-1}$ de N, 17,5 Kg.ha ${ }^{-1}$ de P, 88 Kg.ha ${ }^{-1}$ de K, 601,2 Kg.ha ${ }^{-1}$ de Ca e $158 \mathrm{Kg} \cdot \mathrm{ha}^{-1}$ de $\mathrm{Mg}$.

A biomassa epígea total determinada para cada ecossistema foi de 103,9 t.ha $^{-1}$ para o plantio recente $\left(9,6 \%\right.$ nas folhas e $90,4 \%$ no tronco), de 96,3 t.ha ${ }^{-1}$ para o plantio antigo ( $4,7 \%$ nas folhas e $95,3 \%$ no tronco) e de 67,1 t.ha ${ }^{-1}$ para vegetação natural $(10,1$ \% nas folhas e $89,98 \%$ no tronco). A quantidade de nutrientes alocados na vegetação natural foi de $343 \mathrm{Kg} \cdot \mathrm{ha}^{-1}$ de N, 16,8 Kg.ha ${ }^{-1}$ de P, 265,7 Kg.ha ${ }^{-1}$ de K, 110,8 Kg.ha ${ }^{-1}$ de Ca e 126,5 Kg.ha ${ }^{-1}$ de $\mathrm{Mg}$. No plantio de E. saligna o estoque de nutrientes na vegetação foi de 307,8 Kg.hä ${ }^{-1}$ de N, 20,8 Kg.ha ${ }^{-1}$ de P, 124,8 Kg.ha ${ }^{-1}$ de K, $138 \mathrm{Kg} \cdot \mathrm{ha}^{-1}$ de Ca e $72,9 \mathrm{Kg} \cdot \mathrm{ha}^{-1} \mathrm{de} \mathrm{Mg}$. No plantio de $E$. grandis o estoque de nutrientes na vegetação foi de 451,9 Kg.ha ${ }^{-1}$ de N, $32 \mathrm{Kg} \mathrm{ha}^{-1}$ de P, 418,8 Kg.ha ${ }^{-1}$ de K, 151,4 Kg.ha ${ }^{-1}$ de Ca e 157,6 $\mathrm{Kg} \cdot \mathrm{ha}^{-1}$ de $\mathrm{Mg}$.

A quantidade de serapilheira acumulada sobre o solo na área de vegetação natural foi de 10,9 t.ha $^{-1}$, no plantio de E. saligna foi de 17,7 t.ha ${ }^{-1}$ e no plantio de $E$. grandis foi de 23,9 tha ${ }^{-1}$. O estoque de nutrientes na serapilheira acumulada sobre o solo na área de vegetação natural foi de $118,9 \mathrm{Kg}_{\mathrm{g}} \mathrm{ha}^{-1}$ de N, 3,3 Kg.ha ${ }^{-1}$ de P, 5,8 Kg.ha ${ }^{-1}$ de $\mathrm{K}, 34,0 \mathrm{Kg} \cdot \mathrm{ha}^{-1}$ de Ca e 10,4 Kg.ha ${ }^{-1}$ de $\mathrm{Mg}$. Na área de plantio de E. saligna os estoques de nutrientes foram de 146,7 Kg.ha ${ }^{-1}$ de N, 2,2 Kg.ha ${ }^{-1}$ de P, 5,7 Kg.ha ${ }^{-1}$ de K, $60 \mathrm{Kg}$.ha ${ }^{-}$ 
${ }^{1}$ de $\mathrm{Ca}$ e $14,4 \mathrm{Kg} \cdot \mathrm{ha}^{-1}$ de $\mathrm{Mg}$. Para a área de E. grandis os estoques de nutrientes foram 147,6 Kg.ha ${ }^{-1}$ de N, 6,6 Kg.ha ${ }^{-1}$ de P, 6,6 Kg.ha ${ }^{-1}$ de K, 66,9 Kg.ha ${ }^{-1}$ de Ca e 16,7 Kg.ha ${ }^{-}$ ${ }^{1}$ de $\mathrm{Mg}$.

O plantio de E. saligna mostrou uma ligeira diminuição nos estoques de nutrientes no solo quando comparado com a vegetação natural, exceto para o $\mathrm{Mg}$. Os estoques de $\mathrm{N}$ no solo foram os mais afetados pelo plantio, sendo que na área de plantio de $E$. grandis onde se adicionou nutrientes pela adubação o estoque de $\mathrm{N}$ apresentou-se um pouco maior que o da área de E. saligna, porém bem abaixo do estoque da vegetação natural. As quantidades de nutrientes acumuladas na serapilheira de eucalipto foram maiores que na área de vegetação natural, mas com concentrações de nutrientes semelhantes. Na vegetação epígea o $E$. grandis apresenta os maiores estoques de nutrientes quando comparado as áreas de vegetação natural e de plantio de E. saligna. 


\title{
THE EFFECTS OF Eucalyptus spp PLANTATION ON THE NUTRIENT DINAMICS
}

\author{
IN THE SAVANNA REGION OF SÃO PAULO STATE
}

Author: SIMONE APARECIDA VIEIRA

Advisor: Prof. Dr. FÁBIO POGGIANI

\section{SUMMARY}

The porpouse of this work was to identify the influence of homogeneous Eucalyptus sp plantation on the nutrient dynamics in the savanna region of São Paulo state (Estação Experimental de Itatinga ESALQ/USP). The monthly litter production of the savanna and in two Eucalyptus spp plantations areas were studied. One of the plantation was E. saligna, 16 years old and seven times harvested. The other plantation was $E$ grandis, 6 years old that had been fertilized. The $E$. grandis litter production was 7.3 t. ha $^{-1}$ during the period from august 1996 to july 1997 . For the same period, the litter production of the E. saligna was $4.8 \mathrm{thh}^{-1}$ and the savanna produced $5.9 \mathrm{t}^{-\mathrm{ha}^{-1}}$. The savanna produced the higgest ammount of litter from june to november. The E. saligna higgest litter production was in november and december. In the olher months of the 
year it was not observed any variation. The $E$. grandis litter production reduced hardly in the periods of november to december and february to march. The nutrient inputs from the litter to the soil in the natural area was $150 \mathrm{~kg} \cdot \mathrm{ha}^{-1}$.year ${ }^{-1}, 6.7 \mathrm{~kg} \cdot \mathrm{ha}^{-1}$.year ${ }^{-1}, 29.1$ kg.ha ${ }^{-1} \cdot$ year $^{-1}, 91,0$ kg.ha ${ }^{-1} \cdot$ year $^{-1}, 23.2$ kg.ha ${ }^{-1} \cdot$ year $^{-1}$ of N, P, K Ca and Mg respectively.In the E. saligna plantation this input was $84 \mathrm{~kg}^{-\mathrm{ha}^{-1}}$.year ${ }^{-1}, 2.6 \mathrm{~kg} \cdot \mathrm{ha}^{-1}$.year ', $12.6 \mathrm{~kg} \cdot \mathrm{ha}^{-1} \cdot$ year $^{-1}, 43.1 \mathrm{~kg} \cdot \mathrm{ha}^{-1}$.year ${ }^{-1}$ and $12.5 \mathrm{~kg} \cdot \mathrm{ha}^{-1} \cdot$ year $^{-1}$ of N, P, K, Ca and Mg respectively. The $E$. grandis litter nutrient input was $93.3 \mathrm{~kg}^{-\mathrm{ha}^{-1}}$.year ${ }^{-1}, 3.9 \mathrm{~kg} \cdot \mathrm{ha}^{-1}$.year , $21.7 \mathrm{~kg} \cdot \mathrm{ha}^{-1} \cdot$ year $^{-1}, 54.2 \mathrm{~kg} \cdot \mathrm{ha}^{-1}$.year ${ }^{-1}$ and $17.5 \mathrm{~kg} \cdot \mathrm{ha}^{-1} \cdot$.ear $^{-1}$ of N, P, K, Ca and Mg respectively.

The soil amount of nutrient in the $60 \mathrm{~cm}$ layer in the savanna area was $265 \mathrm{~kg}$. ha ${ }^{-}$ ', $20.5 \mathrm{~kg}$. ha ${ }^{-1}, 98.7 \mathrm{~kg}$. ha ${ }^{-1}, 370.8 \mathrm{~kg}$. ha ${ }^{-1}$ and $176.2 \mathrm{~kg}$. ha ${ }^{-1}$ of $\mathrm{N}, \mathrm{P}, \mathrm{K}, \mathrm{Ca}$ and $\mathrm{Mg}$ respectively. In the E. saligna plantation area this amout was $32.9 \mathrm{~kg}$. ha ${ }^{-1}, 14.3 \mathrm{~kg}$. ha ${ }^{-1}$, $66.5 \mathrm{Kg}$. ha ${ }^{-1}, 370.7 \mathrm{Kg}$. ha ${ }^{-1}$ and $182.4 \mathrm{Kg}$. ha ${ }^{-1}$ of N, P, K, Ca and $\mathrm{Mg}$ respectively. In the $E$ grandis area the total amount in this soil layer was $197.5 \mathrm{~kg}$. ha ${ }^{-1}, 17.5 \mathrm{Kg}$. ha ${ }^{-1}, 88$ kg. ha ${ }^{-1}, 601.2 \mathrm{~kg} \mathrm{ha}^{-1}$ and $158 \mathrm{Kg}$. ha ${ }^{-1}$ of $\mathrm{N}, \mathrm{P}, \mathrm{K}, \mathrm{Ca}$ and $\mathrm{Mg}$ respectively.

The estimated E. grandis total overground biomass was 103.9 t. ha ${ }^{-1}(9.6 \%$ leaves and $90.4 \%$ stem). In the $\mathrm{E}$ saligna area the overground estimated biomass was 96.3 t. ha ${ }^{-1}$ ( $4.7 \%$ leaves and $95.3 \%$ stem). In the savanna this amount was 67.1 t. ha ${ }^{-1}$ (10.1\% leaves and $89.98 \%$ stem). The ammount of nutrients in the savanna was $343 \mathrm{~kg}$. $\mathrm{ha}^{-1}, 16.8 \mathrm{~kg} . \mathrm{ha}^{-1}, 265.7 \mathrm{Kg} . \mathrm{ha}^{-1}, 110.8 \mathrm{~kg}$. ha ${ }^{-1}$ and $126.5 \mathrm{~kg}$. ha ${ }^{-1}$ of N, P, K, Ca and $\mathrm{Mg}$ respectively. In the $E$ saligna area, the amount of nutrients in the vegetation was $307.8 \mathrm{~kg} . \mathrm{ha}^{-1}, 20.8 \mathrm{~kg} . \mathrm{ha}^{-1}, 124.8 \mathrm{~kg} . \mathrm{ha}^{-1}, 138 \mathrm{~kg} . \mathrm{ha}^{-1}$ and $72.9 \mathrm{~kg} . \mathrm{ha}^{-1}$ of N. P. K, Ca and $\mathrm{Mg}$ respectively.

In the E. grandis plantation, the amount of nutrients in the vegetation was 451.9 kg. ha ${ }^{-1}, 32 \mathrm{~kg}$. ha ${ }^{-1}, 418.8 \mathrm{~kg}$. ha ${ }^{-1}, 151.4 \mathrm{~kg}$. ha ${ }^{-1}$ and $157.6 \mathrm{~kg}$. ha ${ }^{-1}$ of N. P, K, Ca and $\mathrm{Mg}$ respectively.

The litter amount in the savanna area was $10.8 \mathrm{t}$. ha ${ }^{-1}$. In the E. saligna area this amount was $17.7 \mathrm{t}_{\text {. ha }} \mathrm{a}^{-1}$. In the $E$ grandis plantation this ammount was $23.9 \mathrm{t}^{\mathrm{h}} \mathrm{ha}^{-1}$. 
The amount of nutrients in the savanna litter was $118.9 \mathrm{~kg} . \mathrm{ha}^{-1}, 3.3 \mathrm{~kg} . \mathrm{ha}^{-1}, 5.8$ kg. ha ${ }^{-1}, 34 \mathrm{~kg}$. ha ${ }^{-1}$ and $10.4 \mathrm{~kg}$. ha ${ }^{-1}$ of $\mathrm{N}, \mathrm{P}, \mathrm{K}, \mathrm{Ca}$ and $\mathrm{Mg}$ respectively. In the $E$. saligna area, the nutrient amount was $146.7 \mathrm{~kg}$. ha ${ }^{-1}, 2.2 \mathrm{~kg}$. ha ${ }^{-1}, 5.7 \mathrm{~kg} . \mathrm{ha}^{-1}, 60 \mathrm{~kg}$. ha ${ }^{-1}$ and $14.4 \mathrm{~kg}$. ha ${ }^{-1}$ of $\mathrm{N}, \mathrm{P}, \mathrm{K}, \mathrm{Ca}$ and $\mathrm{Mg}$ respectively. In the E. grandis area these amounts was $147.6 \mathrm{~kg}$. ha ${ }^{-1}, 6.6 \mathrm{~kg}$. ha ${ }^{-1}, 6.6 \mathrm{~kg}$. ha ${ }^{-1}, 66.9 \mathrm{~kg} \mathrm{ha}^{-1}$ and $16.7 \mathrm{~kg}$. ha ${ }^{-1}$ of $\mathrm{N}$, $\mathrm{P}, \mathrm{K}, \mathrm{Ca}$ and $\mathrm{Mg}$ respectively.

It was observed a decay in the nutrient soil amounts of $E$. saligna plantation if compared with the savanna area, except for $\mathrm{Mg}$. The major influences of the Eucalyptus spp plantation was observed in the soil $\mathrm{N}$ amounts. In the $E$. grandis plantation soil that has been fertilized, the $\mathrm{N}$ amount was higher than in the E. saligna area, but in the savanna the $\mathrm{N}$ amount was higher than in the $E$. grandis.

The highest amounts of litter was observed in the E. grandis and E. saligna areas, but with the nutrient concentration values close to the savanna's litter nutrient concentration. The $E$. grandis plantation has the highest amount of overland biomass nutrient amounts of the three areas.

Using technologies like long time rotation and fertilizing can improve the nutrient balance in the plantation areas, because of the litter nutrient inputs, reducing the plantation effects in the soil fertility of savanna. 


\section{INTRODUÇĀO}

A região de cerrado representa grande parte da cobertura vegetal do Brasil. Cerca de 200 milhões de hectares são cobertos por esse tipo de vegetação, o que representa $22 \%$ da área total do Brasil (Ker et al., 1992).

À partir da década de 70, as áreas de cerrado vêm sendo cada vez mais utilizadas para a agricultura, passando a ser consideradas uma nova fronteira agrícola, principalmente devido a sua topografia favorável à mecanização, a posição geográfica e à crescente demanda de alimento e energia.

Em face da acentuada pobreza de nutrientes, acidez elevada e boas condições fisicas e do relevo plano a suave ondulado, os solos sob cerrado têm sido explorados mediante uso intensivo de máquinas e insumos agrícolas, o que têm provocado alterações na fração orgânica e em algumas propriedades destes solos (Nascimento et al., 1991).

A tendência mundial, nos países onde restam poucas áreas de floresta natural, é que nas áreas de agricultura que começam a ser abandonadas devido a seu esgotamento, sejam implantados reflorestamentos (Hunter, 1996). De acordo com esta tendência, a região do cerrado vem sendo cada vez mais utilizada em larga escala para o plantio de florestas homogêneas de exploração.

A manutenção da produtividade das florestas naturais e mesmo das plantadas, quando bem manejadas, está intimamente relacionada com o equilíbrio da ciclagem de nutrientes (Poggiani 1985) . 
$\mathrm{O}$ estudo dos processos que regulam as atividades biológicas do solo em ecossistemas naturais pode fornecer importantes informações sobre op̧ões de manejo que mantenham a sua fertilidade em áreas de plantio (Brown et al., 1994).

Sabe-se que as plantações florestais de rápido crescimento translocam intensamente os nutrientes contidos no solo para a fitomassa arbórea e para a serapilheira.

Este trabalho tem por objetivo verificar o efeito que as plantações florestais com diferentes idades exercem sobre a ciclagem de nutrientes, em relação a uma área de vegetação natural de cerrado no interior do Estado de São Paulo.

Foram objetivos especificos deste trabalho:

a) Quantificar comparativamente a produção de serapilheira e a quantidade de nutrientes minerais devolvidos ao solo através da mesma nas áreas de Eucalyptus spp e vegetação natural, ao longo de um ano.

b) Estimar a fitomassa arbórea e a mineralomassa em cada área de estudo.

c) Estimar a concentração de nutrientes no solo e sua mineralomassa.

d) Quantificar a serapilheira acumulada sobre o solo e sua mineralomassa. 


\section{CONSIDERAÇÕES SOBRE O CERRADO E A CICLAGEM DE NUTRIENTES}

Nas regiões tropicais da Terra as savanas ocupam 18 milhões de $\mathrm{Km}^{2}$ (Rizzini \& Coimbra Filho, 1988). No Brasil o cerrado ocupa uma área de aproximadamente 2 milhões de $\mathrm{Km}^{2}$, distribuídos descontinuamente por doze estados brasileiros (Figura 1). O cerrado engloba regiões fisico-climáticas bastante heterogêneas, sendo que a maior parte da região se enquadra no tipo climático Aw da classificação de Köppen. Na maior parte das áreas de cerrado, $80 \%$ das chuvas se concentram na estação chuvosa, de novembro à março, ocorrendo um período pronunciado de seca (Ker et al., 1992).

A principal classe de solo da região do cerrado é o Latossolo, ocupando uma área de $933.870 \mathrm{Km}^{2}$, que corresponde a $46 \%$ da área total. As areias quartzosas e os podizólicos ocupam $15 \%$ cada e os $24 \%$ restantes são ocupados com classes de solo variadas (Resck, 1992).

Segundo Alvim (1954), a principal causa para o surgimento dos cerrados seria a deficiência de minerais no solo, sendo o fogo a causa secundária. Dentre as teorias para explicar a formação dos cerrados, a única que se baseia em provas experimentais é a que se fundamenta na composição química do solo, que é função, principalmente, de sua origem geológica. $\mathrm{O}$ fator solo, como o que melhor explica a ocorrência de cerrado, é corroborada por Aoki \& Santos (1979). 


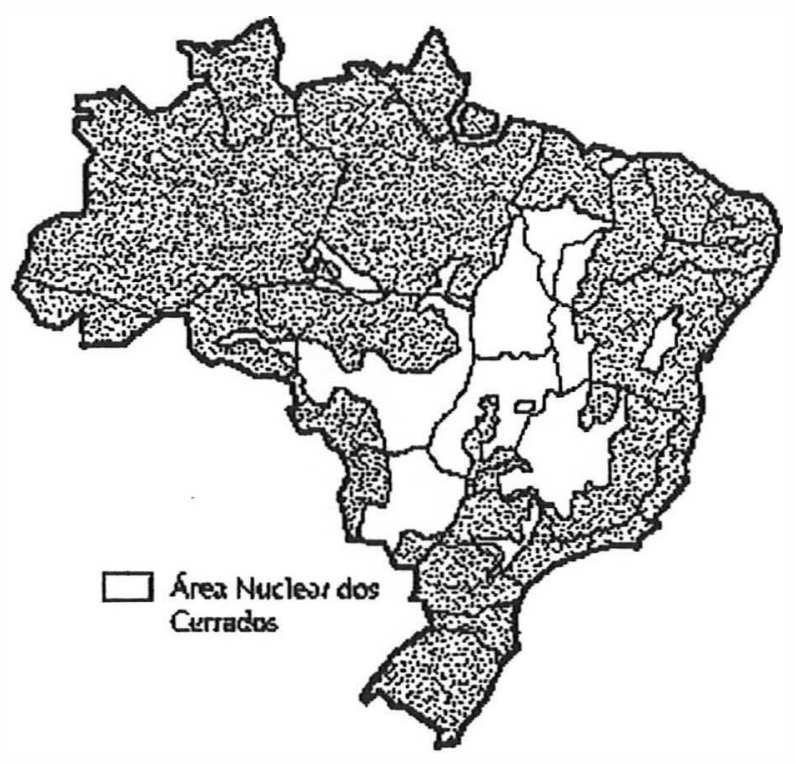

Figura 1. Distribuição da área de Cerrado no Brasil (Fonte: IBGE, 1993)

Coutinho (1978) separa as áreas de cerrado em quatro categorias (Figura 2), que de acordo com o gradiente fisionômico. A biomassa e a concentração de nutrientes no solo e na vegetação aumentam gradativamente do campo sujo até o cerradão. Na mesma ordem, aumentam os valores de $\mathrm{pH}$, sendo a acidez maior no campo sujo, decrescendo até o cerradão.

Aoki \& Santos (1979), interpretando imagens orbitais obtidas em épocas distintas (seca e chuvosa), verificaram que as variações fisionômicas apresentadas pela vegetação de cerrado se devem principalmente ao fator climático. A classificação dos cerrados em quatro formas distintas parece ser a mais adequada pois elas apresentam diferenças em suas principais características, entretanto as diferenças entre elas são graduais, sendo sua separação difícil, a não ser em casos extremos. 


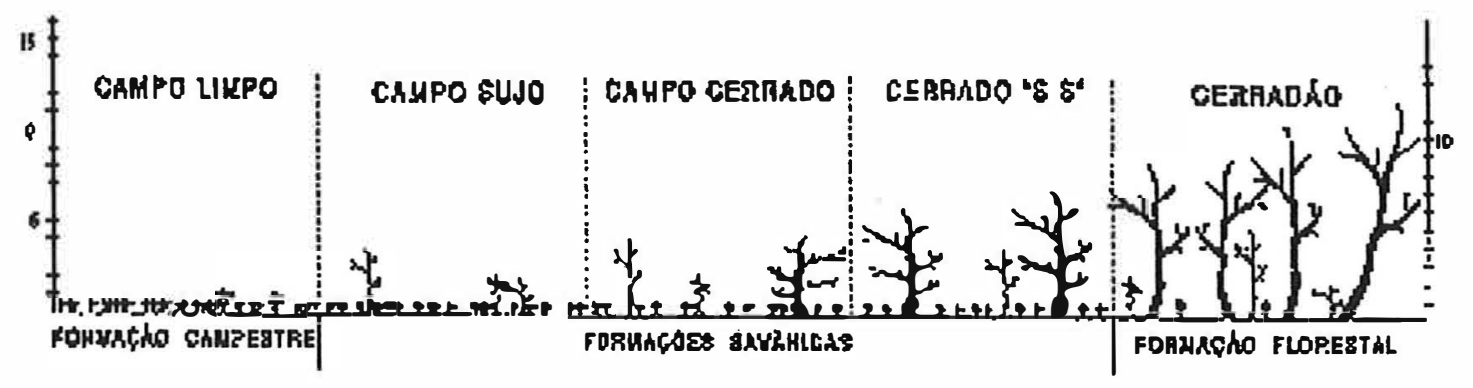

Figura 2. Categorias fisionômicas de cerrado

Fonte: Coutinho (1978)

Estudos realizados por Pagano et al. (1989b) mostraram haver uma considerável variação na estrutura fitossociológica do estrato arbustivo-arbóreo da vegetação de cerrado no Estado de São Paulo, quando comparadas quatro áreas próximas. Essas diferenças se devem mais a fatores edáficos, antrópicos ou ação do fogo e menos a diferenças climáticas.

Segundo levantamento efetuado por Cesar et al. (1988) em uma área de cerrado do município de Corumbataí, no estado de São Paulo, preservado da ação antrópica e de queimadas a mais de 25 anos, encontrou-se que a altura média das árvores era de 4,2 metros, a densidade da vegetação de 9067 indivíduos por hectare, a área basal 9,7 $\mathrm{m}^{2}$ e o volume alcançou $58 \mathrm{~m}^{3}$ por hectare.

No estado de São Paulo, o cerrado ocupa basicamente a região centro-norte (Toledo Filho, 1984), sendo que originalmente $14 \%$ do território eram recobertos por este tipo de formação (Serra Filho, 1974). 
Após a expansão da rede ferroviária para o interior do estado, muitas das áreas de cerrado foram ocupadas por reflorestamentos de Eucaliptus sp (Cavassan, 1990), sendo que atualmente apenas $1,17 \%$ do território do estado se encontra recoberto com cerrado.

A manutenção de extensas áreas de florestas tropicais, onde os solos apresentam baixa fertilidade química, esta intimamente ligada a produção e a decomposição da serapilheira, que permite a reciclagem dos elementos entre o solo e a vegetação (Delitti, 1984).

O movimento dos nutrientes essenciais à vida como o nitrogênio, o fósforo, o potássio e o cálcio, dentro dos ecossistemas pode ser adequadamente denominado de ciclagem de nutrientes

As áreas de vegetação natural, quando em equilibrio, reduzem ao mínimo a saída de nutrientes do ecossistema, através da interação solo-vegetação. Desta forma, o solo mantém sempre o mesmo nível de fertilidade, podendo inclusive melhorar suas características ao longo do tempo. A floresta não perturbada, de forma geral, apresenta uma grande estabilidade, ou seja, os nutrientes introduzidos no ecossistema pela chuva e intemperismo geológico estão em equilíbrio com os nutrientes perdidos para os rios e o lençol freático.

A adoção de práticas culturais interfere nos diversos ciclos do nutriente, modificando-os. No caso das florestas de rápido crescimento a retirada da fitomassa florestal de forma sistemática e por cortes rasos age como um elemento de desequilíbrio nutricional (Poggiani, 1981).

Em ambiente de cerrado, onde de maneira geral os solos são ácidos, com elevada saturação por aluminio, e baixa reserva de nutrientes (Queiroz Neto, 1982), o retorno destes através da serapilheira, decomposta por microrganismos do solo que liberam os nutrientes a taxas possiveis de serem aproveitados pelas plantas florestais, sem riscos de serem perdidos por lixiviação e/ou erosão, assume um importante papel (Melo, 1993). 
Segundo Pereira \& Peres (1985) conservação da matéria orgânica é um dos aspectos mais importantes na manutenção da capacidade produtiva dos solos, especialmente em regiões de cerrado. Entre os principais beneficios trazidos pela manutenção da matéria orgânica estão a maior disponibilidade de nutrientes e a melhoria das propriedades físicas e biológicas do solo

O padrão anual de produção de serapilheira no cerrado é bastante diversificado, sendo comuns os locais onde ocorre produção de material durante todo o ano, alternando períodos de maior ou menor intensidade, devido a fatores ambientais e genéticos.

O material de origem que forma a serapilheira, é uma mistura de diversas partes da estrutura das plantas que vão se acumulando sobre solo, normalmente com maior intensidade durante o outono ou durante os períodos mais secos .

Bray \& Gorham (1964) comentam que os períodos de maior produção de serapilheira são freqüentemente relacionados com à diminuição do fotoperíodo, que ocorre no outono, e/ou a períodos de déficit hídrico, que refletem uma estratégia de resistência a fatores de tensão ambiental, associadas ao aproveitamento máximo dos recursos ambientais.

Na zona tropical, a recirculação de nutrientes pela queda da serapilheira é muito rápida, e compensa a baixa fertilidade do solo. Na composição da serapilheira de florestas tropicais, observa-se uma quantidade de nutrientes por ha/ano cerca de $25 \%$ maior do que nas plantações comerciais (Las Salas, 1983).

Fonseca et al., (1993), verificaram diferenças entre os valores indicadores da atividade microbiana quando se comparou plantação de eucalipto com mata natural. Neste caso a vegetação natural mostrou-se extraordinariamente mais eficiente como recicladora de nutrientes em relação a plantios puros de eucalipto.

Em estudo desenvolvido por Silva et al. (1994) em solos de região da cerrado do oeste baiano sob sucessivos cultivos com soja, verificaram uma redução sistemática nos 
teores de matéria orgânica, sendo que tais perdas resultaram numa redução da CTC, ressaltando-se com isso, a importância do manejo e conservação da matéria orgânica nos ecossistemas de cerrado.

Em solos sob plantio direto, após 4 anos de observações, verificou-se um aumento nos teores de matéria orgânica na camada superficial do solo decorrente do acúmulo de material vegetal deixado na superficie (Santos \& Tomm, 1996).

Segundo Jordan (1985) e Prichett (1987) a matéria orgânica depositada na superfície do solo representa a principal reserva de $\mathrm{N}$ e um importante reservatório de $\mathrm{P}$, $\mathrm{Ca} \mathrm{Ke} \mathrm{Mg.}$

Diversos estudos evidenciam que no ecossistema florestal grande parte dos nutrientes são alocados na árvores. Dentre os componentes da parte aérea da árvore, o maior teor de nutrientes é encontrado nas folhas, em seguida nos ramos e finalmente no lenho do tronco.

De acordo com Poggiani (1983), em plantios de Eucalyptus grandis com 2,5 anos, em densidade de plantio de 5333 árvores/ha, a concentração de nutrientes na biomassa é de aproximadamente $727,7 \mathrm{~kg}$ de nutrientes $(\mathrm{N}, \mathrm{P}, \mathrm{K}, \mathrm{Mg}, \mathrm{Cu}, \mathrm{Fe}, \mathrm{Ca}, \mathrm{Mn}$, $\mathrm{Zn}$ ). Folhas e galhos representam $15,6 \%$ da biomassa total, mas concentram $46,6 \%$ dos nutrientes. O retorno das folhas ao sítio representa uma significativa reposição de nutrientes ao solo.

Segundo Bellote (1993), existe relação entre a produtividade do ecossistema e o fluxo de nutrientes, isto é, maiores fluxos são verificados em ecossistemas mais produtivos.

As regiões de cerrado estudadas até o presente momento, têm apresentado uma menor quantidade de liteira produzida, quando comparada com as florestas de Eucalipto 
Isso talvés deva-se ao fato que algumas florestas implantadas são adubadas, adicionando portanto ao ambiente uma quantidade de nutrientes suplementar. Outra questão a ser considerada é que as espécies utilizadas em florestas implantadas já foram amplamente selecionadas para melhor responder em termos de produtividade, aos recursos que o ambiente oferece, além de serem bastante eficientes na utilização dos nutrientes .

Segundo Poggiani \& Schumacher (1996), a adoção de rotações mais longas, que permitam que a adição de nutrientes pela precipitação atmosférica por um maior período de tempo, sejariam suficientes para suprir os nutrientes anualmente acumulados no lenho do tronco. Esta técnica de manejo poderia representar uma alternativa para minimizar o impacto ambiental das plantações florestais. 


\section{MATERIAIS E MÉTODOS}

\subsection{Caracterização da área}

\subsubsection{Localização e histórico}

A estação Experimental de Ciências Florestais de Itatinga, da Escola de Agricultura "Luiz de Queiroz", localiza-se no município de Itatinga - SP, entre os paralelos $23^{\circ} 02^{\prime} 01^{\prime \prime}$ e $23^{\circ} 02^{\prime} 30^{\prime \prime}$ latitude sul e os meridianos $48^{\circ} 38^{\prime} 34^{\prime \prime}$ e $48^{\circ} 37^{\prime} 30^{\prime \prime}$ latitude oeste de Greenwich, com altitude média de $830 \mathrm{~m}$.

Trata-se de uma área de 2400 ha, que desde a década de 40 vem sendo reflorestada com eucalipto. Inicialmente foi formada para suprir de lenha a Companhia Paulista de Estradas de Ferro. Ela é atravessada pela Rodovia Castelo Branco, que liga a cidade de São Paulo ao interior do Estado (Figura 3).

\subsubsection{Clima}

O clima local é do tipo mesotérmico úmido com verão quente ( $\mathrm{Cfa}$ ), segundo classificação de Köppen, com precipitação média mensal do mês mais seco (julho) entre 30 e $60 \mathrm{~mm}$, temperatura mínima anual de $12,8^{\circ} \mathrm{C}$ e média anual de $19,4^{\circ} \mathrm{C}$. A umidade relativa média anual é de $83,3 \%$, e a precipitação média anual é de $1635 \mathrm{~mm}$.

O balanço hídrico apresenta um excedente de $762 \mathrm{~mm}$, e déficit de $3 \mathrm{~mm}$ nos meses de julho e agosto, com uma evapotranspiração potencial de $877 \mathrm{~mm}$, e capacidade de armazenamento do solo de $150 \mathrm{~mm}$. (Scardua, 1994). 


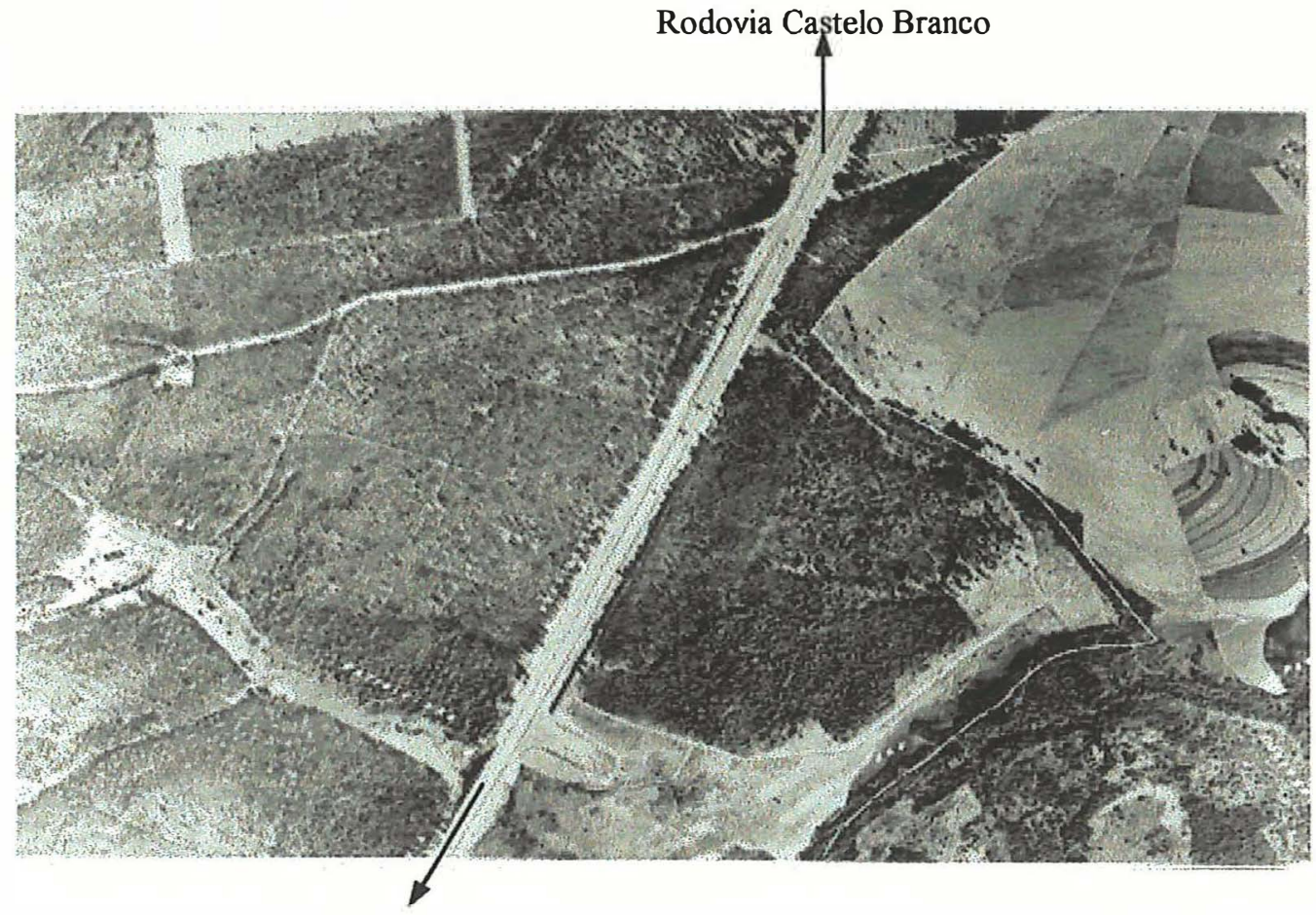

São Paulo

Figura 3. Vista aérea do Horto de Itatinga

\subsubsection{Solo}

A área de estudo é composta por latossolos vermelho-amarelo, álicos, com profundidades superiores a 2 metros. Solos porosos, argilosos, apresentando baixa capacidade de troca catiônica. O relevo é composto por topos aplainados e encostas de forma retilínea ou convexas, apresentando declividade entre 10 e 15\% (Pessotti, 1994). 


\subsubsection{Vegetação}

Os locais em estudo (Figura 4) apresentam a seguinte cobertura florestal:

-Área 1 Fragmento de vegetação natural, contígua ao talhão de Eucaliptus grandis, também na área arrendada, e que constitui uma área de preservação permanente. A área é coberta por cerradão, sendo que, ocorre uma transição de cerradão para mata nas partes baixas do terreno, próximas ao curso d’água.

No ano de 1965 todo o fragmento foi atingido por um grande incêndio, que afetou fortemente as partes altas do terreno.

A vegetação da área se encontra em processo de regeneração (figura 5) sendo comum a presença de lianas. As principais espécies arbóreas presentes na área estão relacionadas na Tabela 1 .

-Área 2 - (Plantio antigo) - Formado por talhões de Eucalyptus saligna Smith iniciados no ano de 1945. Os talhões são geralmente retangulares, medindo aproximadamente 500 $\mathrm{m} \times 350 \mathrm{~m}$, plantados no espaçamento $4 \mathrm{~m} \mathrm{X} 4 \mathrm{~m}$, com uma densidade inicial de 625 árvores. $\mathrm{ha}^{-1} \mathrm{e}$ conduzidos por talhadia.

À partir de 1947 foi realizada a extração de lenha desta área. Nos anos seguintes, foi conduzida rebrota e extração de brasões para a confecção de dormentes para estradas de ferro. Esta atividade prosseguiu até o ano de 1978. Em 1981 a área foi totalmente atingida por um incêndio, que queimou totalmente a vegetação, sendo que após esta data não se conduziu nenhuma atividade para o manejo dos talhões. As atuais árvores são resultantes das brotações após o incêndio. As árvores apresentam altura média de 11,76 m. Como sofreram vários cortes e as brotações não foram conduzidas, as árvores não apresentam um único tronco (figura 6), mais vários troncos com DAP variando de 5 a 27 $\mathrm{cm}$, sendo o DAP médio de $12,16 \mathrm{~cm}$. 
Atualmente a densidade arbórea no talhão é de 333 árvores.ha ${ }^{-1}$, com uma média de 3 brotações por árvore inicial, totalizando 1000 árvores.ha $^{-1}$.

-Área 3. - Talhão de Eucaliptus grandis Hill ex Maiden (figura 7) - Plantio recente, manejado. A área foi plantada em 1991 pela "Companhia Suzano de Papel e Celulose", arrendatária da área.

Foi utilizado o espaçamento $3 \times 1,8 \mathrm{~m}$ que conferiu a área uma densidade de 1852 árvores.ha ${ }^{-1}$.

A área recebeu adubação de plantio de 80 g.planta $^{-1}$ de NPK na formulação 10:20:10 e 70 g.planta $^{-1}$ de FAPS. Após 3 meses foi realizada uma adubação de cobertura, na qual se utilizou 80 g.planta $^{-1}$ de NPK na formulação 10:20:10. Visando a manutenção da produtividade foi realizada uma adubação de cobertura aos 2 anos na qual foram aplicados $300 \mathrm{Kg} \cdot \mathrm{ha}^{-1}$ de NPK na formulação 10:20:10.

A altura média das árvores em maio de 1997 era de $17,10 \mathrm{~m}$ e o DAP de 14,35 $\mathrm{cm}$. 


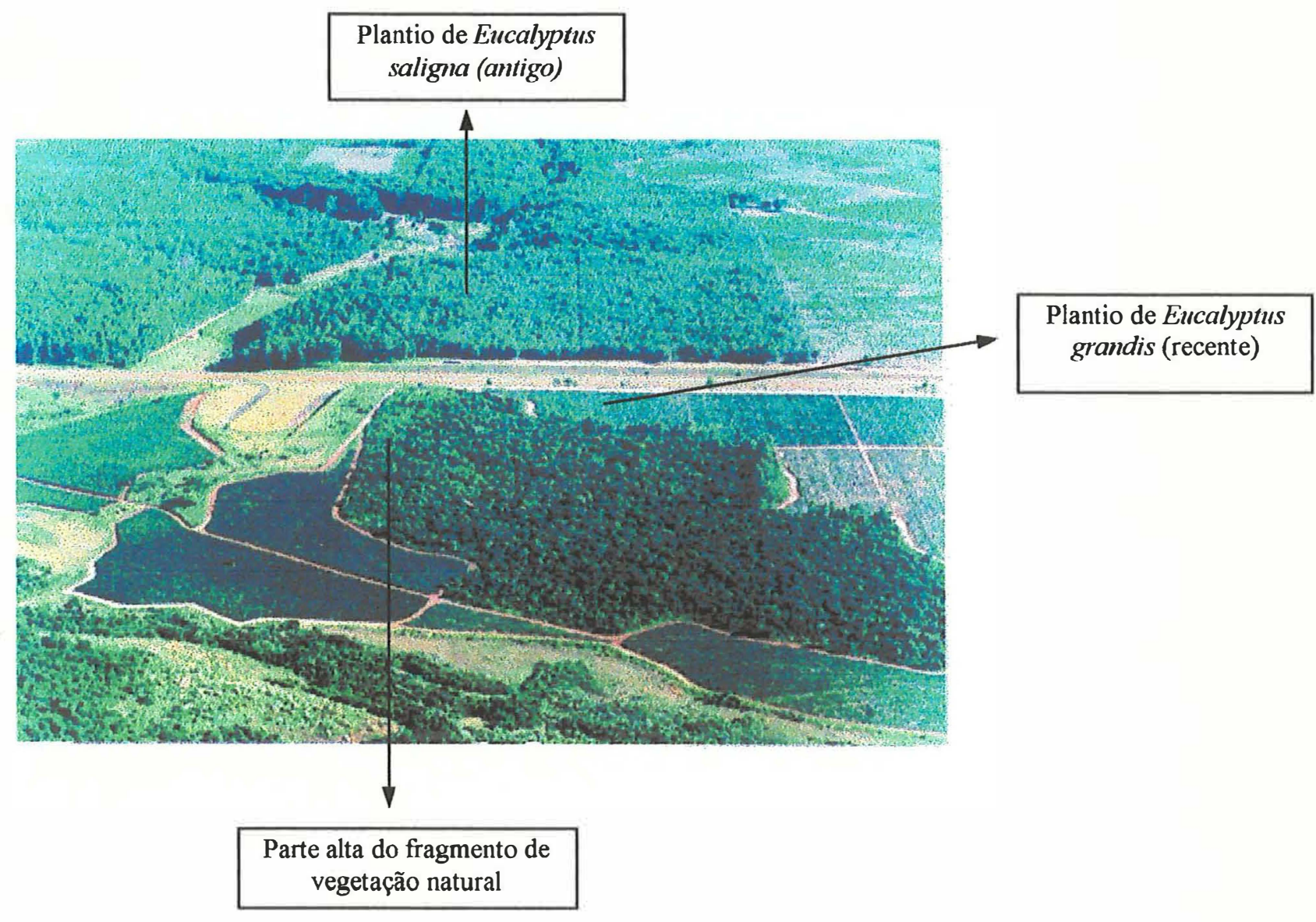

Figura 4. Localização das áreas de estudo 


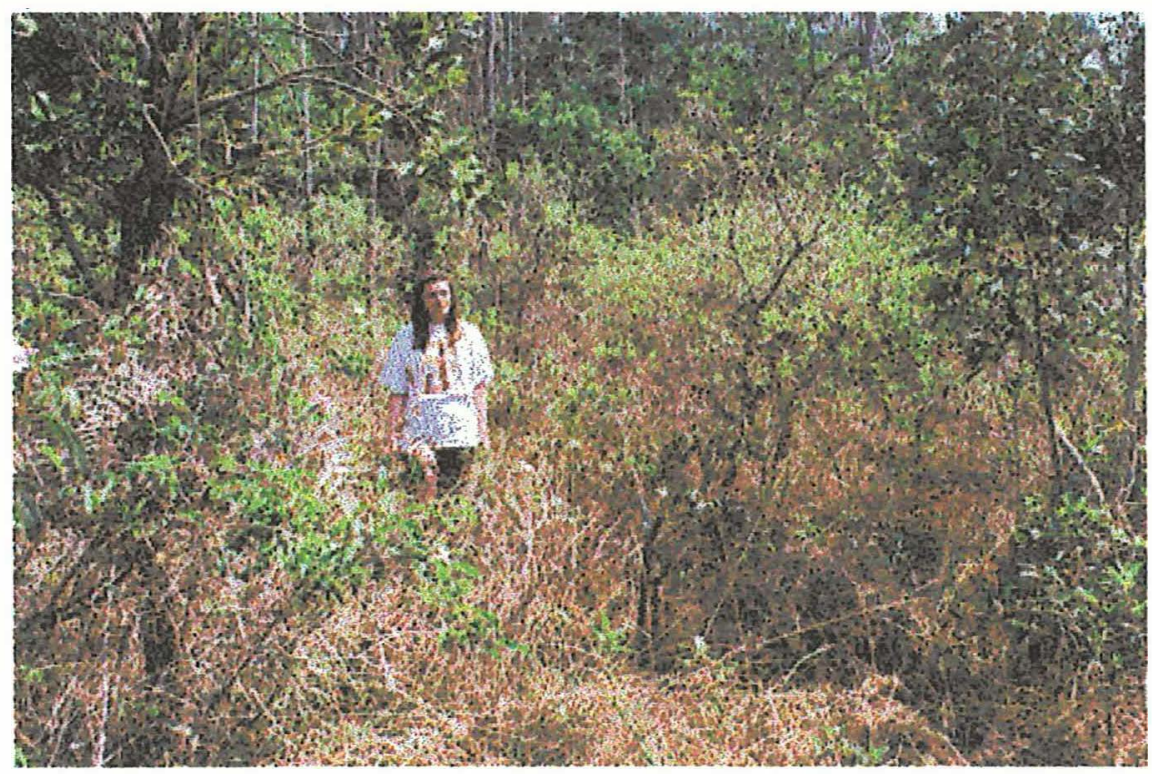

Figura 5. Vista geral da área de vegetação natural da Estação Experimental de Itatinga, SP.

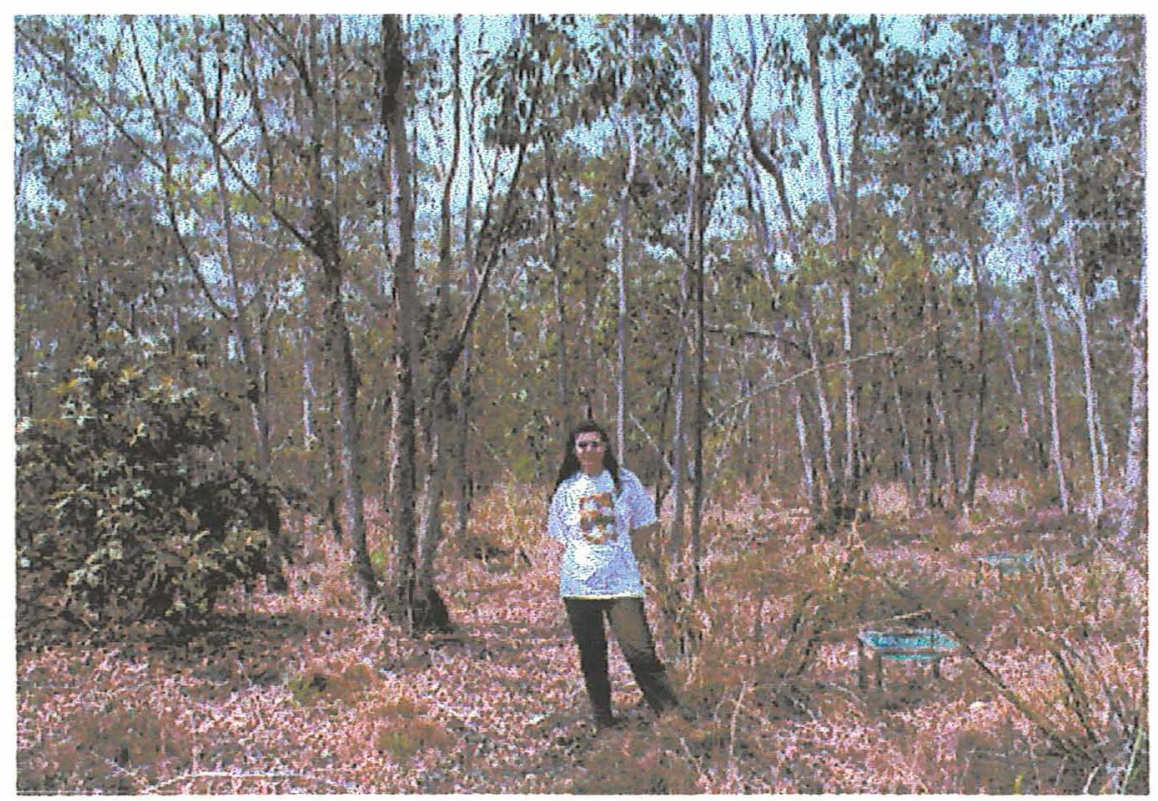

Figura 6. Vista geral do plantio de Eucalyptus saligna 


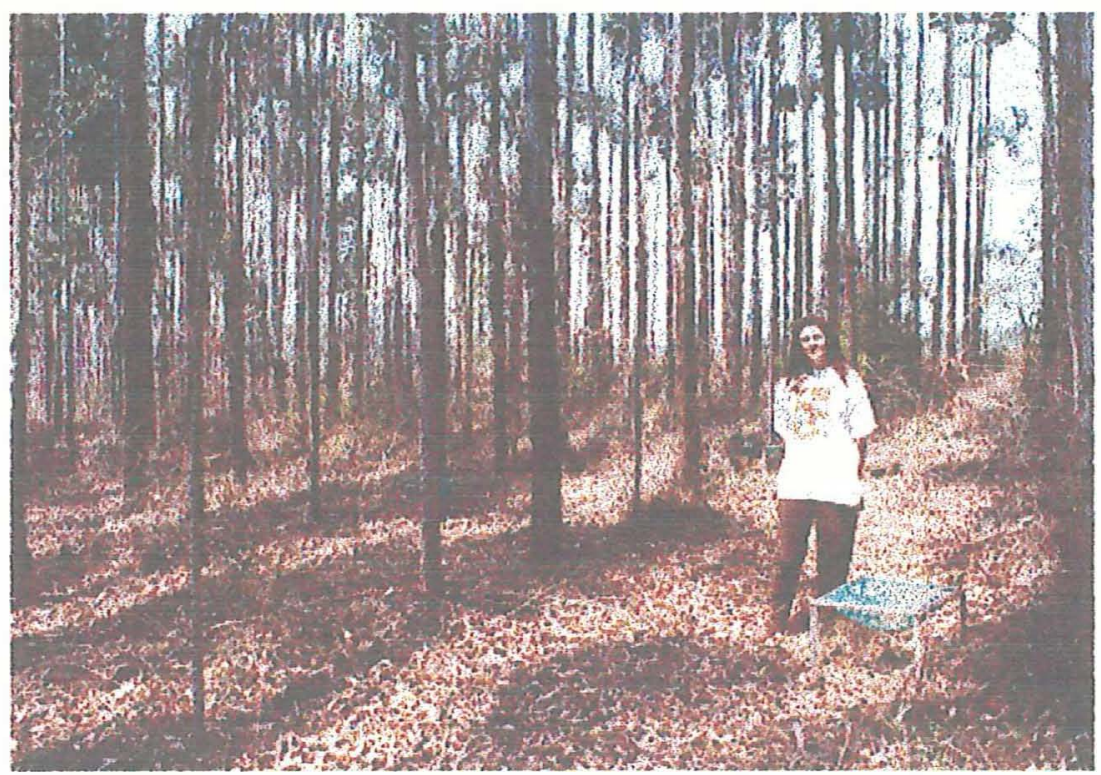

Figura 7. Vista geral do plantio de Eucalyptus grandis 
Tabela 1. Lista das principais espécies presentes em 1997 na área de vegetação natural em regeneração do Horto de Itatinga

\begin{tabular}{|c|c|}
\hline Nome Vulgar & Nome específico \\
\hline Angico & Anadenanthera falcata (Benth.) Speg. \\
\hline Barbatimão & Stryphnodendron adstringes (Mart.) Coville \\
\hline Cambará & Gochnatia polymorpha (Less.) Cabr. \\
\hline Cambuí & Myrciaria tenella (DC.) Berg \\
\hline Canela & Ocotea corymbosa (Meissn.) Mez. \\
\hline Capixinguí & Croton floribundus Spreng. \\
\hline Carvãozinho & Diptychandra aurantiaca (Mart.) Tul. \\
\hline Copaíba & Copifera langsdorfii Desf. \\
\hline Jacarandá Paulista & Machaerium villosum Vog. \\
\hline Jacarandá-Do-Campo & Marchaerium acutifolium Raddi \\
\hline Maçaranduba & Persea pyrifolia Ness et Mart. ex Ness \\
\hline Pimentinha & Xylopia aromatica (Lan.) Mart. \\
\hline Tamanqueira & Pera glabrata (Scott) Baill. \\
\hline Unha-De-Vaca & Bauhinia forficata Link \\
\hline
\end{tabular}




\subsection{Metodologia}

\subsubsection{Produção de serapilheira}

\section{a ) Distribuição das bandejas}

Para a determinação da produção de serapilheira foi demarcada uma área de $30 \mathrm{~m}$ X 50m nos dois talhões de Eucalyptus, onde foram distribuídas aleatoriamente 25 coletores de madeira com telas de náilon de $2 \times 2 \mathrm{~mm}$, com $0.25 \mathrm{~m}^{2}(0.5 \times 0.5 \mathrm{~m})$, a 20 $\mathrm{cm}$ de altura. $\mathrm{Na}$ área de vegetação natural foram distribuídos 45 coletores sistematicamente ao longo das picadas abertas no meio da vegetação. Tomou-se o cuidado de colocar os coletores a uma distância mínima de 1,5 metros da picada. Todos os coletores foram numerados com placas plásticas presas com arame aos coletores.

\section{b ) Período e freqüência das coletas}

As folhas armazenadas nos coletores foram coletadas ao final de cada mês, e acondicionadas em sacos de papel Kraft. Os sacos de papel continham o número de identificação de cada bandeja.

As coletas foram realizadas no período de agosto de 1996 a julho de 1997, perfazendo um total de 12 meses.

\section{c) Processamento e análise do material coletado}

As amostras acondicionadas em sacos de papel foram levadas para o Laboratório de Ecologia Aplicada do Departamento de Ciências Florestais da ESALQ/USP, postas a secar em estufa de circulação forçada a $70-80^{\circ} \mathrm{C}$, até atingir o peso constante. Em seguida processava-se a pesagem das amostras em balança de precisão.

Depois de pesadas as amostras foram agrupadas, formando 3 amostras compostas de cada um dos ecossistemas. A relação das bandejas que formaram cada uma das amostras compostas se encontram na Tabela 2, conforme a ordem de coleta. 
O material vegetal era moído em moinho tipo Willey, com malha de 20 mesh sendo então acondicionadas em sacos plásticos e encaminhado para a análise química.

As análises foram realizadas pelo Laboratório de Ecologia Aplicada do Departamento de Ciências Florestais da ESALQ/USP, e pelo Laboratório do Departamento de Ciência do Solo, também da ESALQ/USP.

Os elementos determinados foram: Nitrogênio $(\mathrm{N})$, Fósforo $(\mathrm{P})$, Potássio $(\mathrm{K})$, Cálcio (Ca) e Magnésio (Mg).

O Nitrogênio foi determinado por titulação ácida após passagem por microdestilador de Kjedahl. O Fósforo foi analisado em fotocolorímetro, utilizando-se o método do vadano-molibidato de amônio. Os nutrientes Potássio, Cálcio e Magnésio foram determinados através da espectrofotometria de absorção atômica, segundo metodologia descrita por Sarruge \& Haag (1974).

A quantidade de nutrientes depositada foi determinada multiplicando-se a biomassa seca depositada (serapilheira) pela concentração média mensal determinada para cada elemento.

Tabela 2. Identificação da procedência das amostras formadoras de cada amostra composta de serapilheira depositada

\begin{tabular}{|c|c|c|c|c|c|c|c|c|}
\hline Am. 1 & $\begin{array}{l}\text { Área } \\
\text { Am.2 }\end{array}$ & $\begin{array}{l}1 \\
\text { Am.3 }\end{array}$ & Am. 1 & $\begin{array}{l}\text { Área } \\
\text { Am. } 2\end{array}$ & $\begin{array}{l}2 \\
\text { Am.3 }\end{array}$ & Am. 1 & $\begin{array}{l}\text { Área } \\
\text { Am.2 }\end{array}$ & $\begin{array}{l}3 \\
\text { Am.3 }\end{array}$ \\
\hline 1 & 2 & 3 & 1 & 2 & 3 & 1 & 2 & 3 \\
\hline 4 & 5 & 6 & 4 & 5 & 6 & 4 & 5 & 6 \\
\hline 7 & 8 & 9 & 7 & 8 & 9 & 7 & 8 & 9 \\
\hline 10 & 11 & 12 & 10 & 11 & 12 & 10 & 11 & 12 \\
\hline 13 & 14 & 15 & 13 & 14 & 15 & 13 & 14 & 15 \\
\hline 16 & 17 & 18 & 16 & 17 & 18 & 16 & 17 & 18 \\
\hline 19 & 20 & 21 & 19 & 20 & 21 & 19 & 20 & 21 \\
\hline 22 & 23 & 24 & 22 & 23 & 24 & 22 & 23 & 24 \\
\hline \multirow[t]{7}{*}{25} & & & 25 & & & 25 & 26 & 27 \\
\hline & & & & & & 28 & 29 & 30 \\
\hline & & & & & & 31 & 32 & 33 \\
\hline & & & & & & 34 & 35 & 36 \\
\hline & & & & & & 37 & 38 & 39 \\
\hline & & & & & & 40 & 41 & 42 \\
\hline & & & & & & 43 & 44 & 45 \\
\hline
\end{tabular}




\subsubsection{Concentração dos nutrientes no solo}

Em cada área de estudo foram tomados quatro pontos de amostragem de solo distribuídos aleatoriamente na parcela. Em cada ponto foram coletadas três amostras nas seguintes profundidades: $0-10 \mathrm{~cm} ; 10-30 \mathrm{~cm}$ e $30-60 \mathrm{~cm}$. O solo de cada amostra foi homogeneizado formando assim uma amostra composta de cada profundidade em cada um dos pontos amostrais e enviado ao Laboratório do Departamento de Ciência do Solos, onde foram executadas as análises. Os teores de $\mathrm{N}, \mathrm{P}, \mathrm{K}, \mathrm{Ca}, \mathrm{Mg}$ foram determinados conforme metodologia de Raij \& Quaggio (1983).

Para a determinação da mineralomassa estocada no solo, foi feita a conversão dos valores de concentração de nutrientes para $\mathrm{Kg} \cdot \mathrm{ha}^{-1}$, para as profundidades $0-10 \mathrm{~cm}, 10$ $30 \mathrm{~cm}$ e $30-60 \mathrm{~cm}$ e posteriormente somados os valores para obter-se o estoque total de nutrientes no solo até $60 \mathrm{~cm}$ de profundidade.

\subsubsection{Serapilheira acumulada}

Em cada um dos pontos amostrais de solo de cada ecossistema foi coletada uma amostra da manta sobre o solo de $0.25 \mathrm{~m}^{2}$, acondicionada em saco de papel do tipo Kraft e enviada para o Laboratório de Ciência dos Solos da ESALQ/USP para as análises, seguindo-se o mesmo procedimento que foi utilizado para as amostras de serapilheira dos coletores.

A mineralomassa presente na serapilheira acumulada sobre o solo foi determinada multiplicando-se os teores de cada nutriente pela quantidade média de serapilheira acumulada sobre o solo. 


\subsubsection{Estimativa da Biomassa}

A biomassa epígea do talhão de Eucalyptus saligna Smith (área 2) foi estimada através de equações de regressão ajustadas por Batista ${ }^{1}$ (comunicação pessoal), correlacionando DAP com o peso do tronco, peso dos ramos e peso das folhas obtidos por método destrutivo. Para a construção da equação de correlação foram abatidas 36 árvores sendo 12 de cada classe de diâmetro que compreendiam os seguintes intervalos: DAP de 5-12 cm, DAP de 12-19 cm e DAP de 19 até $27 \mathrm{~cm}$. As árvores abatidas foram escolhidas aleatoriamente segundo método proposto por Clark \& Schoeder (1977). Foram pesados em separado, o tronco, as folhas e os ramos e galhos menores que $5 \mathrm{~cm}$. De cada um destes componentes foram retiradas amostras para análise química. As amostras foram pesadas, acondicionadas em saco de papel Kraft e enviadas para o laboratório do de Ecologia Aplicada do Departamento de Ciências Florestais da ESALQ/USP, onde foram postas a secar em estufa de circulação forçada à $60-70{ }^{\circ} \mathrm{C}$ até atingirem peso constante. Foram então moídas em moinho tipo Willey, com malha de 20 mesh e o pó resultante acondicionado em sacos plásticos foi encaminhado para a análise química.

Concomitantemente no campo procedeu-se o inventário de toda a parcela no qual foram tomandas as medidas de DAP e altura.

A biomassa do talhão de Eucaliptus grandis (área 3) foi estimada por equações de regressão propostas por Couto (1983) utilizando-se como variáveis independentes o DAP em centímetros e a altura em metros. Estes parâmetros foram obtidos através de inventário total da parcela.

${ }^{1}$ BATISTA, J.L., comunicação pessoal, 1998 
Para a determinação do estoque de nutrientes na vegetação foram abatidas 3 árvores das quais foram retiradas amostras de tronco + ramos e folhas. As amostras foram acondicionadas em saco de papel Kraft, levadas a estufa de circulação forçada até atingirem peso constante, pesadas e encaminhadas para a análise química no Laboratório de Ciência dos Solos da ESALQ/USP

Para a área de vegetação natural (área 1), a biomassa foi determinada pelo método destrutivo, sendo delimitadas 3 parcelas de $4 \mathrm{~m} \mathrm{X} 4 \mathrm{~m}$ nas quais se cortou todo o material vegetal arbustivo e arbóreo ali existente. O material foi separado em folhas e troncos + ramos e pesado no campo. De cada parcela foram retiradas amostras de folhas e troncos para a determinação da umidade e análise química, seguindo a mesma metodologia utilizada na talhão de E. saligna.

A biomassa média das três parcelas abatidas foi convertida para hectare.

A mineralomassa presente na vegetação foi determinada multiplicando-se o teor de nutrientes em cada compartimento (folhas, troncos e galhos) pela biomassa do mesmo. 


\section{RESULTADOS E DISCUSSÃO}

\subsection{Precipitação}

A precipitação total anual no Horto de Itatinga durante o período de observações foi de 1493,3 mm, sendo que os meses de julho/agosto foram os mais secos, com apenas $52 \mathrm{~mm}$.

A distribuição mensal das chuvas (Figura 8) indica que o mês de janeiro foi o que apresentou a maior precipitação, sendo que este mês respondeu por cerca de $30 \%$ da precipitação total anual. A precipitação média no meses de março-maio foi de 58 mm indicando a ocorrência de um período seco.

Os anos de 1996 e 1997 se mostraram atipicos no que refere a distribuição das chuvas. Nos meses de novembro e dezembro de 1996 ocorreu uma diminuição na precipitação média mensal, sendo que no mês de junho de 1997 verificou-se um aumento na precipitação média. O mesmo padrão foi observado para outras regiões do estado de São Paulo. Esta alteração na distribuição da precipitação pode ser relacionada com o efeito "El Niño".

A modificação do regime de chuva pode alterar a produção de serapilheira, bem como a concentração sua concentração de nutrientes. A velocidade de decomposição da serapilheira também pode ser alterada, afetando a liberação dos nutrientes estocados neste compartimento. 


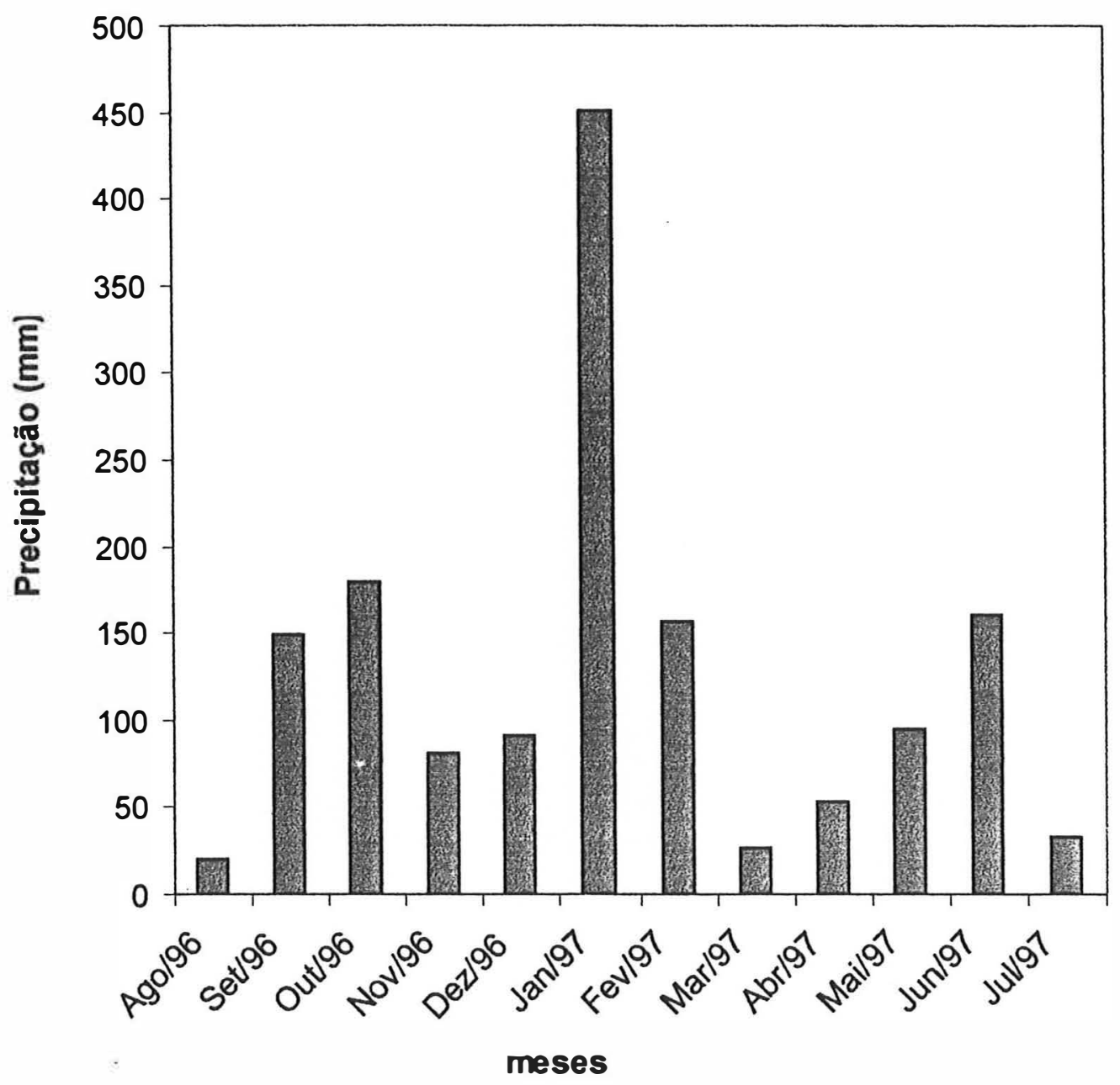

Figura 8. Variação mensal da precipitação no Horto de Itatinga

\subsection{Entrada de nutrientes via precipitação}

A água da chuva carrega para o solo nutrientes solúveis que se encontram em suspensão na atmosfera. Esta entrada de nutrientes no sistema contribui para o balanço global de nutrientes, uma vez que adiciona nutrientes constantemente ao meio. Esta adição se torna ainda mais importante em ecossistemas florestais onde a vegetação perene permite que a adição de nutrientes pela precipitação seja mais efetiva devido ao processo de reciclagem. 
Para a região de Botucatu próxima a Itatinga, Mafra (1996) encontrou as seguintes concentrações de nutrientes na precipitação: $1,09 \mathrm{mg} \cdot \mathrm{L}^{-1}$ de N, $0,19 \mathrm{mg} \cdot \mathrm{L}^{-1}$ de $\mathrm{P}, 0,37 \mathrm{mg} . \mathrm{L}^{-1}$ de $\mathrm{K}, 0,90 \mathrm{mg} \cdot \mathrm{L}^{-1}$ de Ca e $0,17 \mathrm{mg} \cdot \mathrm{L}^{-1}$ de $\mathrm{Mg}$, estimando-se uma adição de nutrientes pela precipitação de $15,5 \mathrm{Kg}_{\mathrm{ha}}{ }^{-1} \cdot \mathrm{ano}^{-1}$ de N, 2,82 Kg.ha ${ }^{-1} \cdot \mathrm{ano}^{-1}$ de P, 5,35 Kg.ha ${ }^{-1}$.ano ${ }^{-1}$ de K, 13,0 Kg.ha ${ }^{-1}$.ano ${ }^{-1}$ de Ca e 2,42 Kg.ha ${ }^{-1}$.ano ${ }^{-1}$ de $\mathrm{Mg}$.

Este dado deve ser tomado apenas como referência, não sendo parte desta pesquisa.

Todavia Poggiani \& Schumacher (1997) assinalam valores inferiores aos observados por Mafra (1996)

\subsection{Solos}

\subsubsection{Caracteristicas químicas do solo}

O teor médio de nutrientes encontrado no solo da área de vegetação natural, dos talhões de Eucalyptus saligna (plantio antigo) e de Eucalyptus grandis (plantio recente) se encontram na Tabela 3.

Através da análise de variância verificou-se que os únicos parâmetros que apresentaram diferença significativa ao nível de $5 \%$ entre os ecossistemas foram nitrogênio total, $\mathrm{H}+\mathrm{Al}$, matéria orgânica e CTC. Os demais parâmetros não diferiram significativamente entre os ecossistemas.

Os menores valores de $\mathrm{pH}$ em $\mathrm{CaCl} 2$ foram encontrados para à área de plantio recente, apresentando na profundidade $0-10 \mathrm{~cm}$ um valor de $\mathrm{pH}$ de 3,70 , um pouco abaixo do encontrado para o plantio antigo e vegetação natural, que foi de 3,85 .

A área de plantio de E. grandis foi adubada em três ocasiões o que pode ter resultado numa acidificação do solo. 
$\mathrm{O}$ pH apresentou um ligeira elevação em profundidade nas três áreas em estudo, sendo o maior valor 4,13 encontrado na área do plantio recente na profundidade de $30-60 \mathrm{~cm}$. O aumento do $\mathrm{pH}$ em profundidade pode ser devido a adição contínua de serapilheira ao solo. A tendência de aumento do $\mathrm{pH}$ em profundidade também foi observada por Mafra (1996) em uma área de cerrado próxima ao município de Botucatu.

Os maiores teores de matéria orgânica foram observados nos primeiros $30 \mathrm{~cm}$ do solo, passando de 33,5 g. $\mathrm{dm}^{3}$ na profundidade de $0-10 \mathrm{~cm}$ para $17,5 \mathrm{~g} \cdot \mathrm{dm}^{3}$ na profundidade de 30-60 cm, na área de vegetação natural. A área que possui os maiores teores de matéria orgânica é o plantio recente de Eucalyptus grandis, porém este não diferiu significativa do conteúdo de matéria orgânica da vegetação natural, sendo que esta diferença só foi significativa entre as parcelas de plantio recente e vegetação natural quando comparadas com a parcela do plantio antigo. Segundo Nascimento et al. (1993) as características da matéria orgânica nas regiões de cerrado pressupõe uma alta resistência a alterações em decorrencia de fatores externos. Esta resistência pode ser atribuída parcialmente a insolubilidade dos colóides de húmus pelos oxidos de $\mathrm{Fe}$ e $\mathrm{Al}$.

Os três ecossistemas apresentaram valores significativamente diferentes de nitrogênio total no solo. A área de vegetação natural foi a que apresentou valor mais elevado, seguida do plantio recente. Os menores valores de $\mathrm{N}$ total foram encontrados na área do plantio antigo.

Os valores de $\mathrm{N}$-total foram os que mais variaram tanto entre as três áreas, quanto em profundidade, sendo que no plantio recente a concentração na camada de 30-60 $\mathrm{cm}$ foi de 0,33\%, apresentando-se 10 vezes maior que nas duas primeiras camadas do solo da mesma área. Nas camadas de $0-10 \mathrm{~cm}$ e $10-30 \mathrm{~cm}$ na vegetação natural a concentração de nitrogênio total foi a maior encontrada sendo de $0,90 \% \mathrm{e}$ $0,43 \%$ respectivamente. $\mathrm{O}$ maior teor de $\mathrm{N}$-total, apresentado pela área de vegetação natural, é posssivelmente devido à fixação simbiótica através das numerosas espécies de leguminosas presentes na área. 


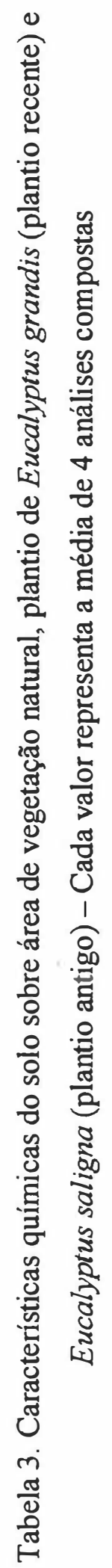

\begin{tabular}{|c|c|c|c|}
\hline & $\overline{2}: 9$ & $0 \%$ & 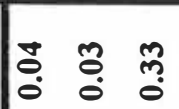 \\
\hline$\equiv$ & 욤 & 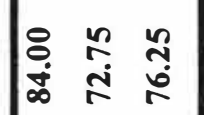 & 雚 \\
\hline & 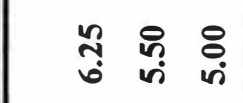 & 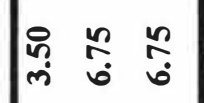 & 褊 \\
\hline . & 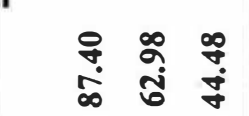 & $\mid \begin{array}{ll}0 \\
0 \\
0\end{array}$ & 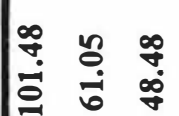 \\
\hline$\dot{8}$ & 导 & 芯 & 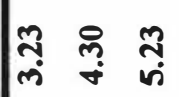 \\
\hline & 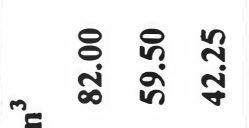 & $\mid$ & 点 \\
\hline & 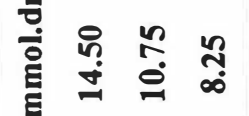 & 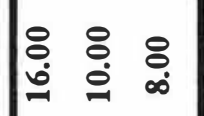 & 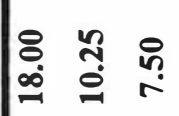 \\
\hline 20 & $\stackrel{n}{\leftrightarrows} \stackrel{్}{9}$ & 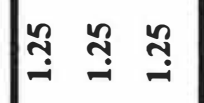 & 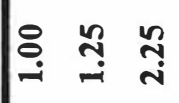 \\
\hline & 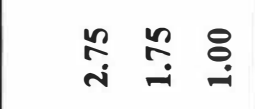 & $\dddot{丶}$ & $\overbrace{i=i}^{n}$ \\
\hline & 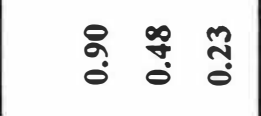 & 号高管 & 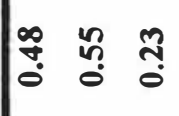 \\
\hline & 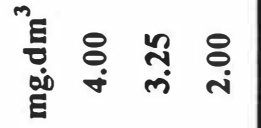 & 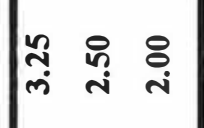 & 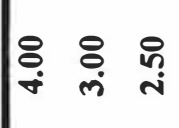 \\
\hline & 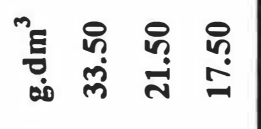 & 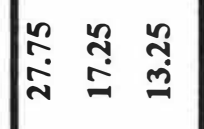 & 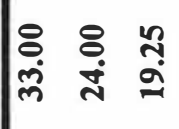 \\
\hline & 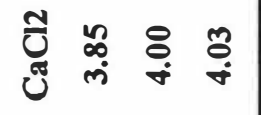 & 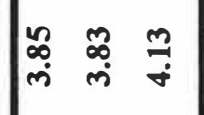 & 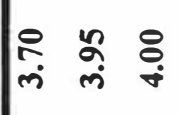 \\
\hline & 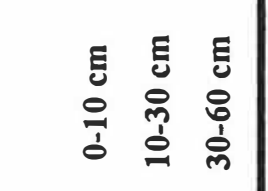 & 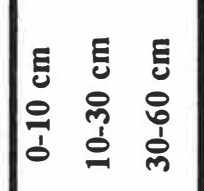 & 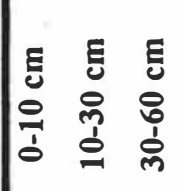 \\
\hline$\stackrel{8}{8}$ & 赵 & 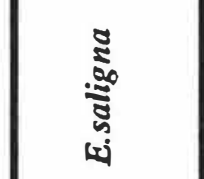 & 急 \\
\hline
\end{tabular}


Os valores de $\mathrm{H}+\mathrm{Al}$ foram diferentes apenas entre o plantio antigo e o recente, não havendo diferenças significativas entre estes ecossistemas e a parcela de vegetação natural. O mesmo resultado foi observado para a variável $\mathrm{T}$ (capacidade de troca catiônica).

A relação $\mathrm{C} / \mathrm{N}$ na área de vegetação natural é mais baixa, favorecendo a liberação mais rápida do $\mathrm{N}$ contido nas folhas através do processo de decomposição

Nas parcelas com eucalipto, embora a quantidade de serapilheira produzida seja maior, o $\mathrm{N}$-total é menor, pois o material com alta relação $\mathrm{C} / \mathrm{N}$ requer mais tempo para a liberação deste nutriente.

O Ca não diferiu entre os ecossistemas, estando as áreas em estudo com conteúdos de Ca no solo acima do nível crítico para o crescimento do eucalipto que segundo o por Braga (1995), é de $0,5 \mathrm{mmol}_{\mathrm{c}} \mathrm{dm}^{-3}$. Entre as áreas estudadas o menor valor de Ca para a profundidade de $0-10 \mathrm{~cm}$ foi $1,25 \mathrm{mmmol} . \mathrm{dm}^{3}$ no plantio antigo e o maior teor, $2,75 \mathrm{mmmol} . \mathrm{dm}^{3}$ na área de vegetação natural, sendo que no plantio recente este teor ficou em $1,75 \mathrm{mmmol} . \mathrm{dm}^{3}$.

$\mathrm{Na}$ profundidade de $30-60 \mathrm{~cm}$, a área que apresentou as maiores concentrações de Ca foi o plantio recente com 2,75 mmmol.dm ${ }^{3}$. Verificou-se que nas áreas de vegetação natural e no plantio de $E$. saligna a concentração de $\mathrm{Ca}$ diminui em profundidade, enquanto que na área de plantio de E. grandis a concentração de $\mathrm{Ca}$ aumentou em profundidade. $\mathrm{O}$ Ca que se encontra em profundidade no plantio de $E$. grandis deve ser proveniente do fertilizante que foi adicionado ao solo.

Apesar do conteúdo de $\mathrm{K}$ não ter sido significativamente diferente, a área de vegetação natural evidenciou o dobro de $K$ na profundidade de $0-10 \mathrm{~cm}$, quando comparado com as áreas de plantio de eucalipto. 
Para o Al parece ocorrer a mesma coisa visto que, apesar de não haver diferença significativa entre os ecossistemas, o conteúdo de Al na camada superficial da área do plantio recente é maior do que na área de vegetação natural. Nas demais profundidades as concentrações de $\mathrm{Al}$ são semelhantes.

\subsubsection{Estoque de nutrientes no solo}

Os estoques de nutrientes no solo, até $60 \mathrm{~cm}$ de profundidade, variaram em função do ecossistema e do nutriente em questão.

Em relação à matéria orgânica, as maiores quantidade foram encontradas no solo sob plantio de E. grandis $\left(138,8\right.$ t.ha $\left.^{-1}\right)$. Na área de vegetação natural a quantidade de matéria orgânica no solo foi de 129 t.ha ${ }^{-1}$, sendo que as menores quantidades observadas ocorreram no solo sob plantio de E. saligna, com 102 t.ha $^{-1}$ (Figura 10).

Dentre os nutrientes analisados o que apresentou as maiores variações entre os ecossistemas foi o nitrogênio (Figura 10.) sendo que o plantio de E. saligna (plantio antigo) foi o que apresentou os menores valores, quando comparado com as outras duas áreas. O estoque de nitrogênio no solo, até $60 \mathrm{~cm}$ de profundidade, foi de $265 \mathrm{Kg} \cdot \mathrm{ha}^{-1}$ para a área de vegetação natural, $197,5 \mathrm{Kg} \cdot \mathrm{ha}^{-1}$ para a área sob plantio de E. grandis (plantio recente) e de $24,5 \mathrm{Kg}$ ha $^{-1}$ para a área sob plantio de E. grandis (plantio antigo).

O fósforo foi o nutriente que apresentou os menores estoques nas três áreas em estudo. O estoque de fósforo no solo variou de $14,3 \mathrm{Kg} \cdot \mathrm{ha}^{-1}$ à $17,5 \mathrm{Kg} \mathrm{ha}^{-1}$ entre os ecossistemas, sendo que os maiores valores foram encontrados sob o plantio de E.grandis. Este esta diretamente relacionado com a adição de fósforo pelas adubações efetuadas. 


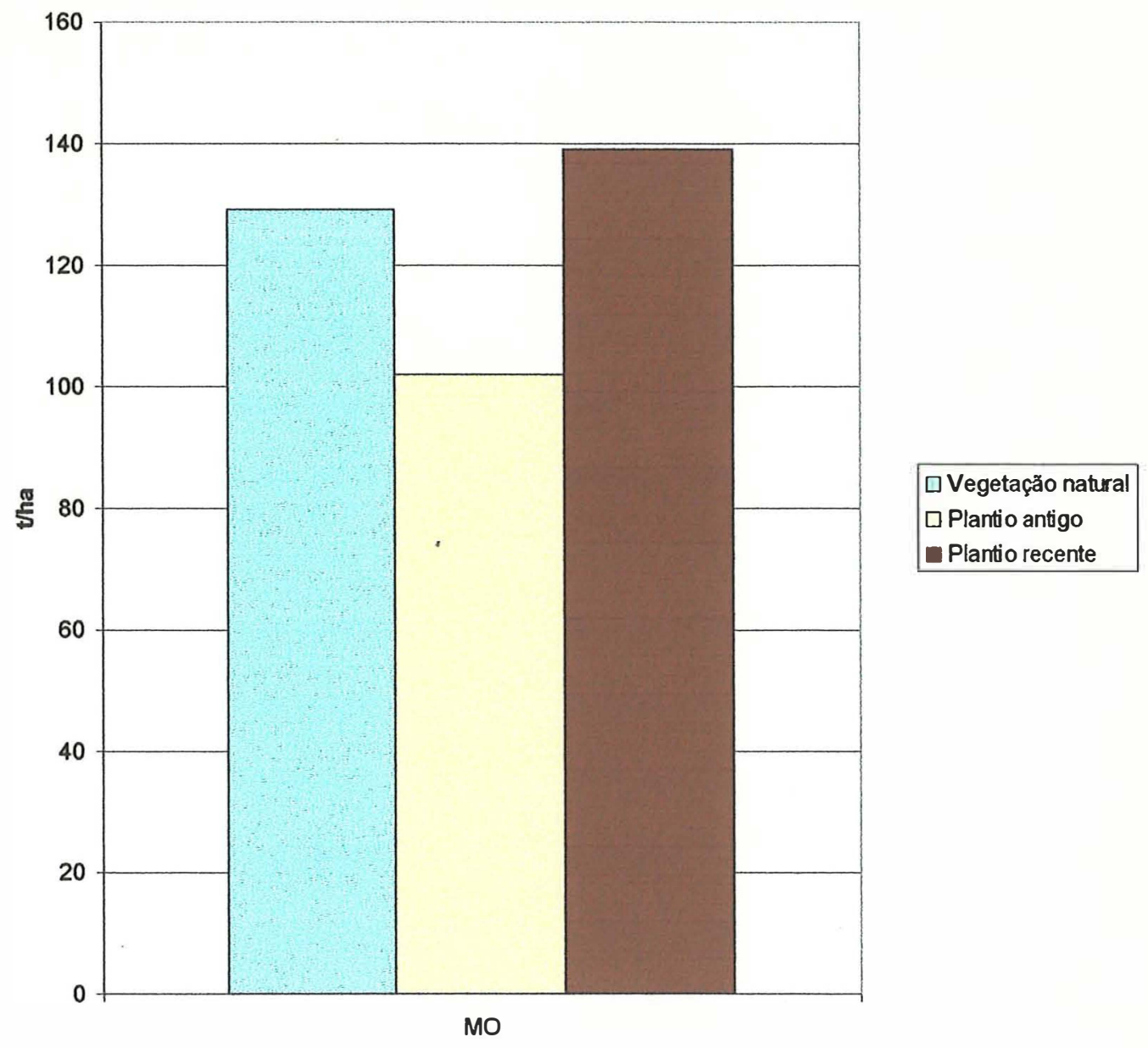

Figura 9. Estoque de matéria orgânica no solo, até $60 \mathrm{~cm}$ de profundidade, em área sob vegetação natural, plantio de E. saligna (plantio antigo), E. grandis (plantio recente).

$\mathrm{O} \mathrm{Ca}$ foi outro nutriente que diferiu significativamente no solo, entre os ecossistemas. A área de vegetação natural e do plantio de $E$. saligna (plantio antigo) apresentaram iguais quantidades de $\mathrm{Ca}$ estocadas no solo. $\mathrm{O}$ solo sob plantio de $E$. grandis (plantio recente) apresentou um estoque de $601 \mathrm{Kg}^{-h^{-1}} \mathrm{de} \mathrm{Ca}^{2} 2$ vezes maior 
do que o encontrado para as outras áreas e, como no caso do fósforo, possivelmente proveniente da adubação.

As diferenças no estoque de nutrientes entre os ecossistemas (Tabela 4.) nas profundidades de $0-10 \mathrm{~cm}, 10-30 \mathrm{~cm}$ e $30-60 \mathrm{~cm}$ reflete o efeito que as plantações florestais podem causar sobre o solo quando não manejadas, ou manejadas inadequadamente.

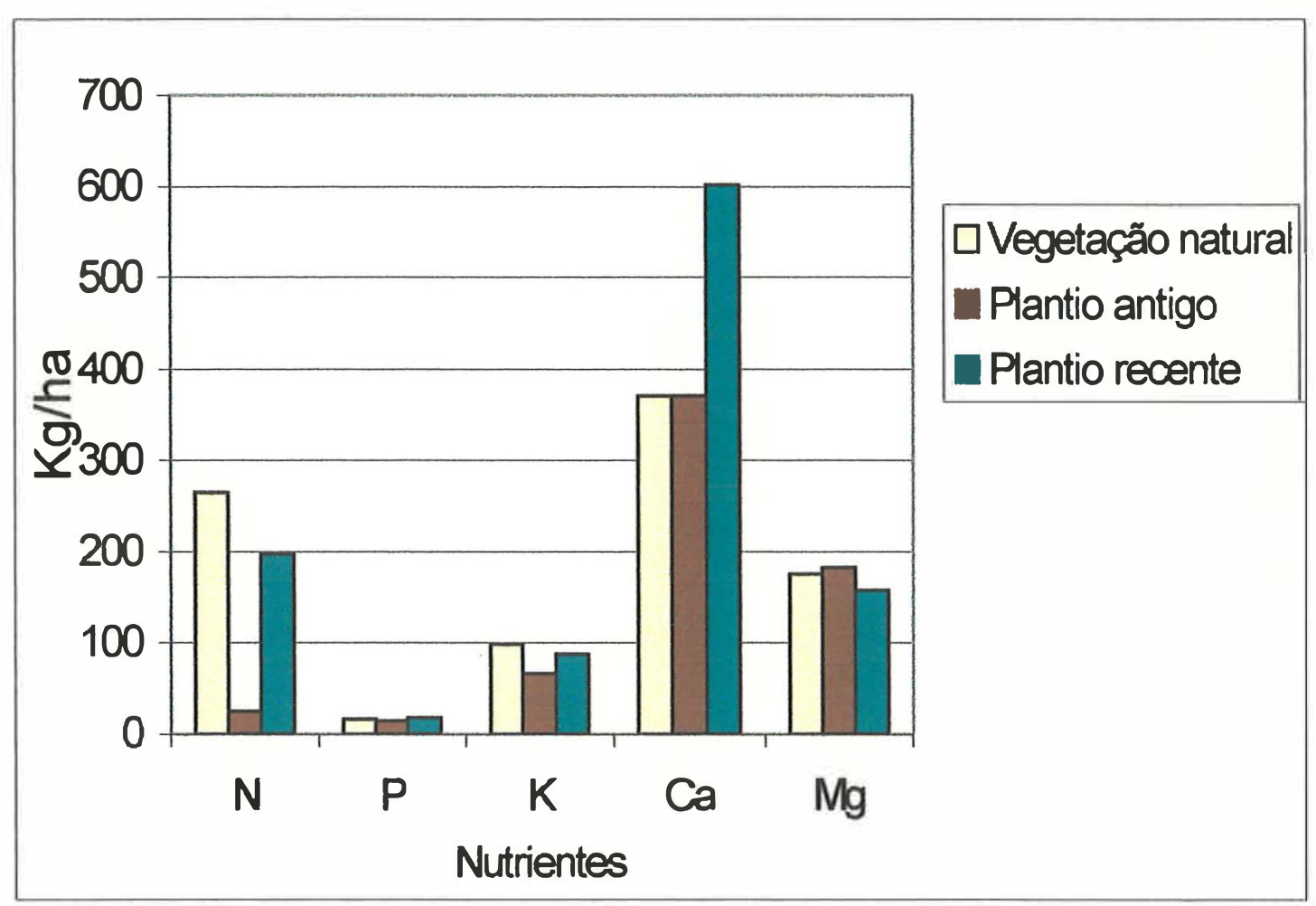

Figura 10. Estoque de nutrientes (N, P, K, Ca e Mg) no solo até $60 \mathrm{~cm}$ de profundidade em área sob plantio de E. saligna (plantio antigo), E. grandis (plantio recente) e vegetação natural em região de cerrado do Estado de São Paulo. 


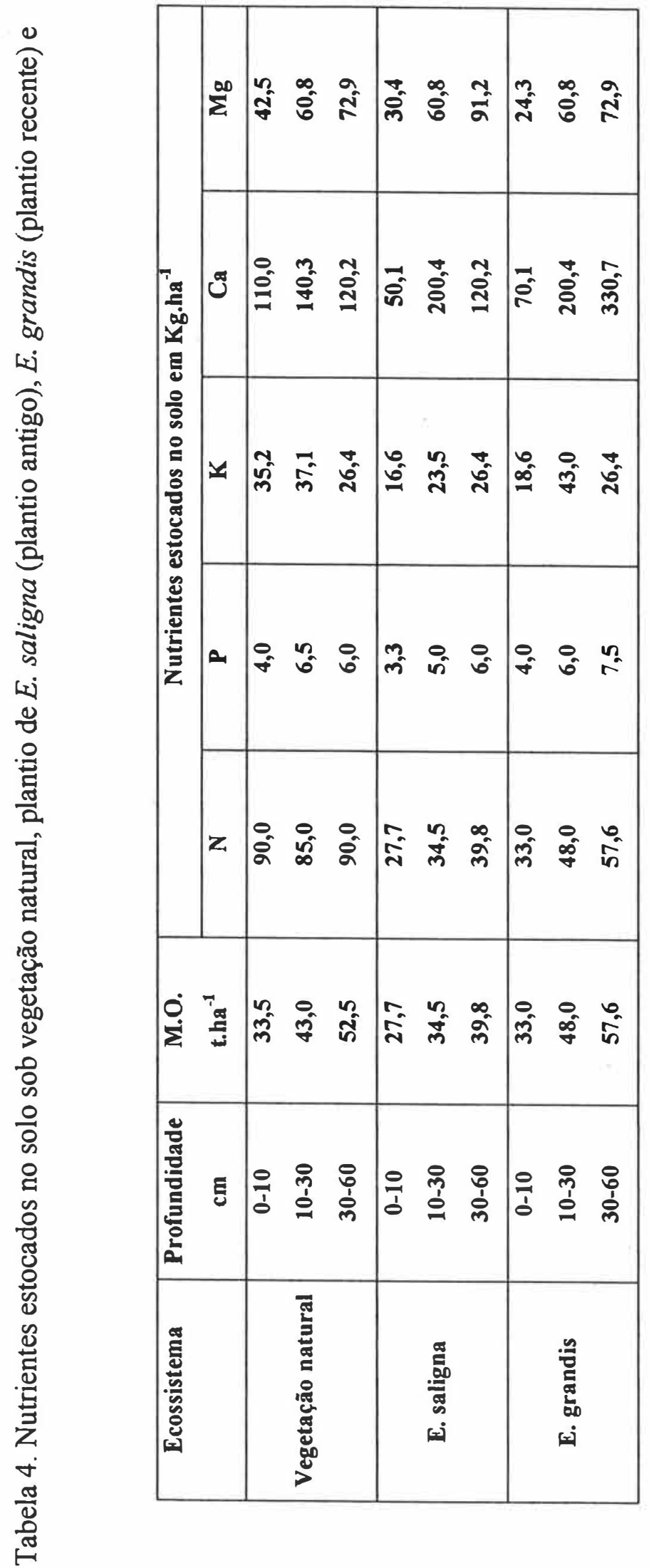


De maneira geral os solos não apresentaram diferenças significativas em suas características químicas. A principal diferença entre os solos estudados foi em relação ao $\mathrm{N}$ total. A vegetação natural mostrou-se mais eficiente na conservação do $\mathrm{N}$. Devido a presença de leguminosas na área que fixam o $\mathrm{N}$ do ar, liberando-o para o meio. $\mathrm{O} \mathrm{N}$ nestes ecossistemas mostra-se maior que a que nas áreas cobertas apenas por plantios homogêneos de eucalipto. No plantio de E. saligna onde não se aplicou nenhum tipo de manejo, a única entrada do nitrogênio ocorreu pela precipitação. No caso do plantio de E. grandis, esta entrada ocorreu também através da adubação.

Além disto, a serapilheira da área de vegetação natural apresenta uma composição mais variada devido a alta diversidade florística encontrada na área, o que facilita sua decomposição, pois permite que um maior número de espécies de microorganismos se envolvam no processo de decomposição, liberando os nutrientes mais rapidamente para o solo.

De acordo com Poggiani (1996), os microorganismos decompositores nem sempre se adaptam facilmente a espécies exóticas, como é o caso do eucalipto, o que causa maior lentidão na decomposição da serapilheira depositada sobre o solo.

\subsection{Biomassa epígea}

\subsubsection{Plantio recente}

Para estimativa de biomassa arbórea foram utilizados os parâmetros adotados por Couto (1983) e obtidas as seguintes equações:

Biomassa foliar : 
Onde:

$P S F=$ Peso seco das folhas $(\mathrm{Kg})$

$D=$ DAP em $\mathrm{cm}$.

Coeficiente de Determinação $\left(\mathrm{R}^{2}\right)$ da equação (1) foi de 0,9107 e o Erro Padrão $(\text { Sy.x })^{2}=0,061$.

Biomassa do tronco:

$P S T=0,07753+0,00961 D^{2} H$

Onde:

$P S T=$ Peso seco do Tronco $(\mathrm{Kg})$

$D=\mathrm{DAP}$ em $\mathrm{cm}$

$H=$ altura em metros.

O Coeficiente de Determinação $\left(R^{2}\right)$ da equação (2) foi de 0,9501 e o Erro Padrão (Sy.x $)^{2}=0,435$.

Biomassa dos galhos: 
Onde:

$P S G=$ Peso seco dos galhos $(\mathrm{Kg})$

$D=\mathrm{DAP} \mathrm{em} \mathrm{cm}$.

O Coeficiente de Determinação $\left(\mathrm{R}^{2}\right)$ da equação (3) foi de 0,7813 e o Erro Padrão $(\text { Sy.x })^{2}=0,093$.

A biomassa de cada compartimento foi calculada primeiramente para a parcela inventariada. O valor de biomassa obtido para a parcela foi transformado para hectare.

A biomassa resultou da soma do peso seco das folhas, do tronco e dos galhos. A parte lenhosa é considerada a soma do peso seco dos galhos e tronco.

$\mathrm{Na}$ área do plantio recente, com uma densidade de plantio de 2024 árvores.ha ${ }^{-1}$ a biomassa epígea encontrada foi de 103,9 tha ${ }^{-1}$ de matéria seca (Tabela 5) estando distribuídos. $90,4 \%$ na parte lenhosa e $9,6 \%$ nas folhas.

Schumacher (1992), em trabalho realizado na Estação Experimenta de Anhembi, verificou que em plantios de Eucalyptus grandis com 9 anos de idade, a biomassa total era de $273,3 \mathrm{t}$ ha ${ }^{-1}$. A biomassa das folhas foi de $8,5 \mathrm{tha}^{-1}$, que corresponde a apenas $3,1 \%$ da biomassa total.

Em um povoamento de Eucalyptus grandis de 6,4 anos no município de Viçosa, MG, Soares et al. (1996) encontraram que a biomassa das folhas correspondia a 2,1\% da biomassa total. No presente estudo a biomassa foliar correspondeu a 9,6 \%. 
Tabela 5. Biomassa epígea de um plantio de E.grandis de 6 anos em t.ha ${ }^{-1}$ e a $\%$ presente em cada um dos compartimentos

\begin{tabular}{ccc}
\hline Biomassa de E.grandis & t.ha $^{-1}$ & $\%$ \\
\hline Tronco & 82,4 & 79,3 \\
Folhas & 9,9 & 9,6 \\
Galhos & 11,6 & 11.1 \\
Tronco + Galhos & 93,9 & 90,4 \\
\hline Total & $\mathbf{1 0 3 , 9}$ & 100 \\
\hline
\end{tabular}

Em um povoamento de Eucalyptus grandis de 6,41 anos no município de Viçosa, Soares et al. (1996) encontraram a biomassa que a biomassa das folhas correspondia a $2,1 \%$ da biomass total. No presente estudo a biomassa foliar correspondeu a $9,6 \%$.

As diferenças encontradas por vários autores na biomassa de plantios homogêneos de Eucalyptus grandis decorrem de vários fatores, dentre eles as diferenças climáticas entre as áreas, as diferenças edáficas, a densidade de plantio e principalmente os tratos culturais a ele dispensados. 


\subsubsection{Plantio Antigo}

As equações para a determinação da biomassa epígea do plantio de E.saligna (plantio antigo) foram:

Peso seco do tronco:

$P S T=10,38099+(-4,638834 * D)+\left(0,6307953 * D^{2}\right)$

Onde:

$P S T=$ Peso seco do tronco $(\mathrm{Kg})$

$D=\operatorname{DAP}(\mathrm{cm})$

O Coeficiente de Determinação $\left(R^{2}\right)$ da equação (4) foi de 0,9506 e o Erro Padrão Residual $(\text { Sy.x })^{2}=0,0676$.

Peso seco das folhas:

$P S F=1,922904+\left(-0,4238664^{*} D\right)+\left(0,04024448^{*} D^{2}\right)$

Onde:

$P S F=$ Peso seco da folhas $(\mathrm{Kg})$

$D=\operatorname{DAP}(\mathrm{cm})$ 
O Coeficiente de Determinação $\left(\mathrm{R}^{2}\right)$ da equação (5) foi de 0,7448 e o Erro Padrão Residual (Sy.x $)^{2}=0,008814$.

Peso seco dos galhos:

$P S G=16,10865+(-2,835563 * D)+\left(0,1757495 * D^{2}\right)$

Onde:

$P S G=$ Peso seco dos galhos $(\mathrm{Kg})$

$D=\operatorname{DAP}(\mathrm{cm})$

O Coeficiente de Determinação $\left(\mathrm{R}^{2}\right)$ da equação (6) foi de 0,6197 e o Erro Padrão Residual (Sy.x $)^{2}=0,03007$.

A biomassa de cada compartimento foi calculada primeiramente para a parcela inventariada. $\mathrm{O}$ valor de biomassa obtido para a parcela foi transformado para hectare.

A biomassa resultou da soma do peso seco das folhas, do tronco e dos galhos. A parte lenhosa é considerada a soma do peso seco dos galhos e tronco.

A biomassa total para o plantio de E. saligna foi 96,3 t. ha ${ }^{-1}$ (Tabela 6), sendo que 76,1 t.ha ${ }^{-1}$ estavam alocados no tronco, 4,5 Kg.ha- ${ }^{-1}$ nas folhas e 15,7 t.ha ${ }^{-1}$ nos galhos. Da biomassa total, 95,3\% correspondem a parte lenhosa e 4,7\% as folhas. A Biomassa total do plantio de E. saligna é um pouco inferior do plantio de E. grandis com 6 anos de idade. 
Tabela 6. Biomassa epígea de um plantio de E. saligna de 16 anos em tha ${ }^{-1}$ e a $\%$ presente em cada um dos compartimentos

\begin{tabular}{ccc}
\hline Biomassa de E.saligna & t.ha-1 & $\%$ \\
\hline Tronco & 76,1 & 79,0 \\
Folhas & 4.6 & 4.7 \\
Galhos & 15,7 & 16.3 \\
Tronco + Galhos & 91.8 & 95,3 \\
\hline Total & 96.4 & 100,0 \\
\hline
\end{tabular}

Considerando-se que as árvores avaliadas são resultantes da rebrota dos troncos após o incêndio de 1981, podemos admitir que a idade das árvores é de 16 anos. Portanto a produtividade anual média da área plantada com $E$. saligna foi de 6 t.ha $^{-1}$.ano ${ }^{1}$ e na área de $E$. grandis é de 17 t.ha $^{-1} \cdot$ ano $^{-1}$. A área de plantio de eucalipto na qual se procedeu o manejo, através da utilização de espécie melhorada, adubadas e desbastadas, apresentou uma produtividade média anual 3 vezes superior a do plantio em talhadia (figura 11), não manejado, evidenciando que o manejo do plantio reflete em produtividade e em conservação dos recurso ali existentes, uma vez que as características do solo foram pouco afetadas pelo plantio de $E$. grandis. 


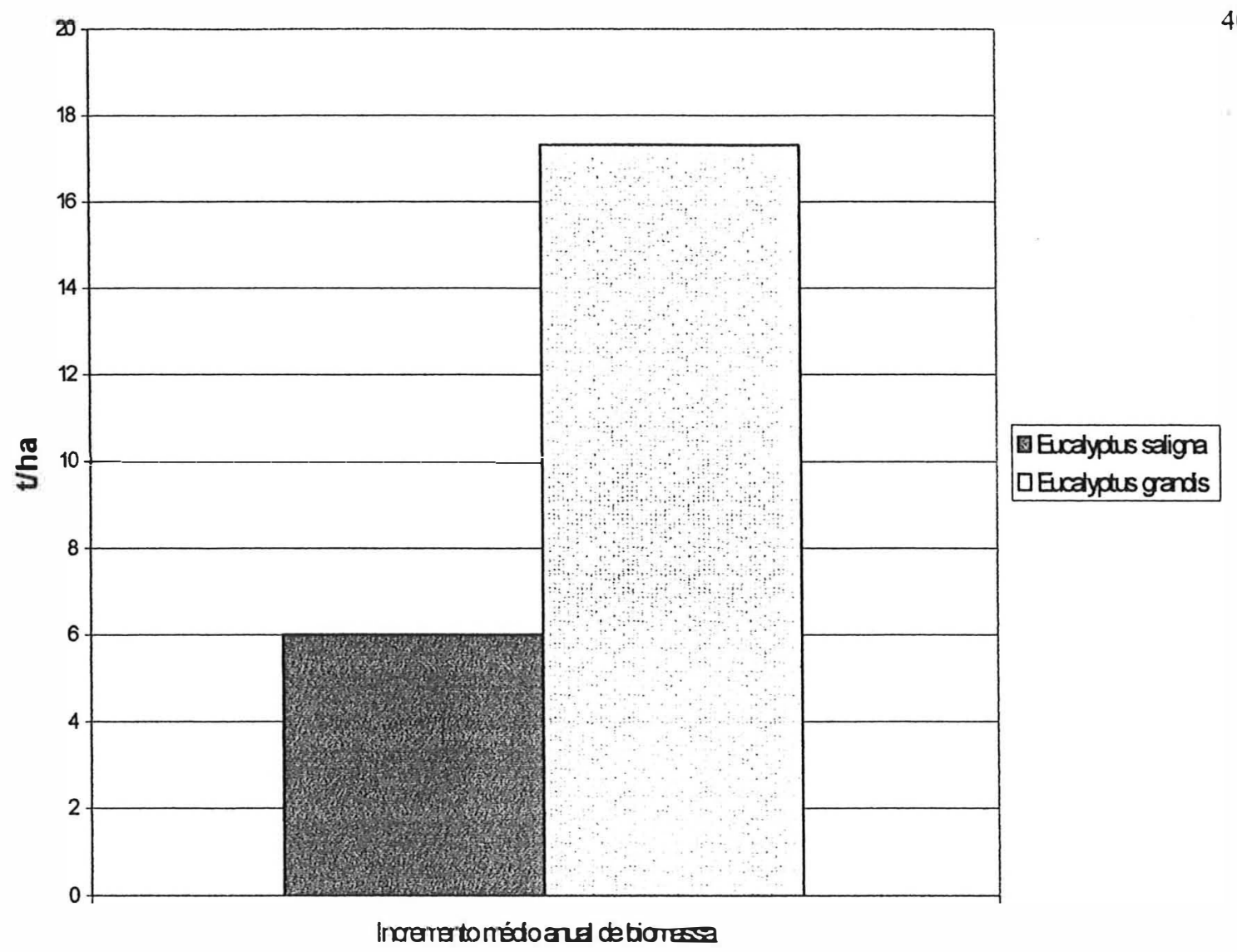

Figura 11. Incremento médio anual de biomassa em plantio de E. saligna (plnatio antigo) e E. grandis (plantio recente).

A área de plantio de eucalipto na qual se procedeu o manejo, através da utilização de espécie melhorada, adubadas e desbastadas, apresentou uma produtividade média anual 3 vezes superior a do plantio em talhadia, não manejado, evidenciando que o manejo do plantio reflete em produtividade e em conservação dos recurso ali existentes, uma vez que as características do solo foram pouco afetadas pelo plantio de E. grandis. 


\subsubsection{Vegetação Natural}

A biomassa da vegetação natural, determinada através do corte da vegetação de 3 parcelas de $16 \mathrm{~m}^{2}$, foi de $67,1 \mathrm{t}^{-1} \mathrm{ha}^{-1}$ dos quais $89,9 \%$ era constituída pela parte lenhosa e $10,1 \%$ pelas folhas (Tabela 7). O valor obtido se aproxima das estimativas de fitomassa arbórea total e parcial obtidos através de método destrutivo por Meguro \& Delitti ${ }^{1}$ para área de cerradão. Segundo os autores, 92,3\% da biomassa se encontra alocada na parte lenhosa e 7,7 \% nas folhas. Na área em estudo houve uma maior locação da biomassa nas folhas, devido a grande quantidade de lianas presentes na área.

Tabela 7. Biomassa epígea de uma área de vegetação natural em regeneração (cerradão).

\begin{tabular}{ccc}
\hline Biomassa Vegetação Natural & t.ha $^{-1}$ & $\%$ \\
\hline Tronco & 60,3 & 89,90 \\
Folhas & 6,8 & 10,10 \\
\hline Total & $\mathbf{6 7 , 1}$ & $\mathbf{1 0 0}$ \\
\hline
\end{tabular}

Em outra área de cerrado no estado de São Paulo, Dellitti (1984) estimou a biomassa em 23.8 t. ha ${ }^{-1}$, sendo distribuída da seguinte maneira: 3.8 t.ha ${ }^{-1}$ são folhas e os 20 t.ha ${ }^{-1}$ restantes são elementos lenhosos.

${ }^{1}$ MEGURO, M. \& DELLITI, W.B.C. Comunicação pessoal, (1997) 
O aumento da biomassa alocada na parte lenhosa, apesar da grande quantidade de lianas presentes na área se deve à presença de árvores altas na área, remanescentes do incêndio de 1965.

A quantidade de biomassa alocada em cada um dos componentes arbóreos bem como o total produzido em cada ecossistema se encontram na tabela 8. Dentre as áreas em estudo, o plantio de E. grandis (plantio recente) foi o que apresentou os maiores valores de biomassa alocada no compartimento folhas que foi de 9,9 thha $^{-1}$. O plantio recente apresentou 4,6 t.ha $^{-1}$ o que representa $4,7 \%$ da biomassa total. A vegetação natural apresentou os menores valores de biomassa da parte lenhosa apresentando no entanto uma biomassa foliar de 6,8 t.ha $^{-1}$, situando-se entre os valores encontrados para os plantios recente e antigo.

Tabela 8. Biomassa estocada na vegetação de três ecossistemas (vegetação natural, Eucalyptus grandis com 6 anos e Eucalypus saligna com 16 anos) no Horto de Itatinga, S.P., em t.ha ${ }^{-1}$

\begin{tabular}{|c|c|c|c|}
\hline Ecossistema & Biomassa Total & Tronco & Folha \\
\hline Vegetação Natural & 67,1 & 60,3 & 6,8 \\
E. saligna & 96,4 & 91,8 & 4,6 \\
E. grandis & 103,9 & 93,9 & 9,9 \\
\hline
\end{tabular}




\subsubsection{Nutrientes na biomassa epígea}

Dentre os compartimento da vegetação, os maiores teores de nutrientes foram encontrados nas folhas, para os três ecossistemas (tabela 9).

A maior concentração de $\mathrm{N}$ foi encontrada nas folhas da vegetação natural com 21,7 g.Kg-1. As folhas do plantio de E. saligna apresentaram $14,6 \mathrm{~g} \cdot \mathrm{Kg}^{-1}$ e o plantio de E. grandis $19,1 \mathrm{~g} . \mathrm{Kg}^{-1}$.

Nos troncos a concentração de $\mathrm{N}$ presente é cerca de 6 vezes menor do que nas folhas para os três ecossistemas. O P apresentou o mesmo padrão em relação a sua concentração nas folhas e no lenho, não diferindo entre os ecossistemas.

O K apresentou maior concentração nas folhas do plantio de $E$. grandis, com 8,7 g. $\mathrm{Kg}^{-1}$. Na vegetação natural o teor de $\mathrm{K}$ foi $8,1 \mathrm{~g} \cdot \mathrm{Kg}^{-1}$ e no plantio de E. saligna 5,3 g. $\mathrm{Kg}^{-1}$.

O teor de Ca nas folhas do plantio de E. saligna foi de $5,5 \mathrm{~g} \cdot \mathrm{Kg}^{-1}$ enquanto que na vegetação natural foi de $4,8 \mathrm{~g} \cdot \mathrm{Kg}^{-1}$ e no plantio de E. grandis $4,3 \mathrm{~g} \cdot \mathrm{Kg}^{-1}$. No tronco os maiores teores foram encontradas na vegetação natural, que foi de $1,3 \cdot \mathrm{g} \cdot \mathrm{Kg}^{-1}$ No plantio de E. saligna o teor de 1,1 g. $\mathrm{Kg}^{-1}$ e no E. grandis $1,0 \mathrm{~g} . \mathrm{Kg}^{-1}$.

As folhas de E. saligna foram as que apresentaram os maiores teores de $\mathrm{Mg}$, refletindo o maior estoque deste nutriente encontrado no solo sob plantio de E. saligna.

O estoque de macronutrientes $(\mathrm{N}, \mathrm{P}, \mathrm{K}, \mathrm{Ca}$ e $\mathrm{Mg}$ ) da vegetação natural foi de $863,1 \mathrm{Kg} \cdot \mathrm{ha}^{-1}$, do plantio de E. saligna de $664,4 \mathrm{Kg} \mathrm{ha}^{-1}$ e do E. grandis foi de 1211,7 Kg. ha ${ }^{-1}$ (Tabela 10). 
Tabela 9. Teor médio de nutrientes nas folhas, galhos e troncos da vegetação de áreas de vegetação natural, E. saligna (plantio antigo) e E. grandis (plantio recente) na região de cerrado do Estado de São Paulo.

\begin{tabular}{|c|c|ccccc|}
\hline & & \multicolumn{5}{|c|}{ Nutrientes em g. $\mathrm{Kg}^{-1}$} \\
& Ecossistema & $\mathrm{N}$ & $\mathrm{P}$ & $\mathrm{K}$ & $\mathrm{Ca}$ & $\mathrm{Mg}$ \\
\hline \multirow{3}{*}{ Folhas } & Vegetação Natural & 21,7 & 0,9 & 8,1 & 4,8 & 2,6 \\
& E. saligna & 14,6 & 1,2 & 5,3 & 5,5 & 2,9 \\
& E. grandis & 19,1 & 1,2 & 8,7 & 4,3 & 1,4 \\
\hline Galhos & E. saligna & 4,3 & 0,3 & 1,9 & 1,9 & 0,9 \\
& E. grandis & 2,3 & 0,1 & 1,9 & 2,6 & 0,9 \\
\hline \multirow{3}{*}{ Tronco } & Vegetação Natural & 3,3 & 0,2 & 3,5 & 1,3 & 1,8 \\
& E. saligna & 2,3 & 0,1 & 0,9 & 1,1 & 0,6 \\
& E. grandis & 2,9 & 0,2 & 3,8 & 1,0 & 1,6 \\
\hline
\end{tabular}

O plantio de E. grandis apresentou os maiores estoques de macronutrientes, que reflete a adaptação da espécie as condições de cerrado e a resposta que esta apresenta à adição de nutrientes via adubação.

A vegetação natural apresentou estoques de macronutrientes maiores que o plantio de $E$. saligna, porém o $\mathrm{P}$ e o $\mathrm{Ca}$ apresentaram-se em maiores quantidades no plantio de E. saligna.

As menores quantidades de nutrientes estocados na vegetação do plantio de $E$. saligna, pode refletir o esgotamento do solo, uma vez que grandes quantidades de nutrientes foram exportadas através da retirada de madeira da área ao longo das sucessivas rotações. 
Tabela 10. Estoque de nutrientes na biomassa epígea de vegetação natutral, E. saligna (plantio antigo) e E. grandis (plantio recente) na região de cerrado do Estado de São Paulo

\begin{tabular}{|c|l|rrrrr|}
\hline & & \multicolumn{5}{|c|}{ Nutrientes em Kg.ha ${ }^{-1}$} \\
& \multicolumn{1}{|c|}{ Ecossistema } & \multicolumn{1}{c|}{$\mathrm{N}$} & $\mathrm{P}$ & $\mathrm{K}$ & $\mathrm{Ca}$ & $\mathrm{Mg}$ \\
\hline \multirow{3}{*}{ Folhas } & Vegetação Natural & 147,0 & 6,1 & 54,7 & 32,4 & 17,9 \\
& E. saligna & 66,8 & 5,5 & 24,2 & 25,0 & 13,3 \\
& E. grandis & 189,7 & 11,6 & 86,6 & 42,8 & 13,9 \\
\hline \multirow{2}{*}{ Galhos } & E. saligna & 68,0 & 5,1 & 29,0 & 29,4 & 13,3 \\
& E. grandis & 26,5 & 1,4 & 21,5 & 30,1 & 10,2 \\
\hline \multirow{3}{*}{ Tronco } & Vegetação Natural & 196,1 & 10,7 & 211,0 & 78,5 & 109,6 \\
& E. saligna & 173,0 & 10,1 & 71,7 & 83,7 & 46,3 \\
& E. grandis & 235,7 & 19,0 & 310,7 & 78,5 & 133,5 \\
\hline \multirow{3}{*}{ Total } & Vegetação Natural & 343,2 & 16,8 & 265,7 & 110,8 & 126,5 \\
& E. saligna & 307,8 & 20,8 & 124,8 & 138,0 & 72,9 \\
& E. grandis & 451,9 & 32,0 & 418,8 & 151,4 & 157,6 \\
\hline
\end{tabular}

\subsection{Serapilheira}

\subsubsection{Produção de serapilheira}

A produção de serapilheira na área com plantio recente de Eucaliptus grandis, foi de 7,3 tha ${ }^{-1}$.ano ${ }^{-1}$, na área de plantio de Eucalyptus saligna (plantio antigo) de 4,8 t.ha ${ }^{1}$.ano ${ }^{-1}$, e na área de vegetação natural 5,9 t.ha $^{-1}$.ano ${ }^{-1}$, como podemos verificar na Figura 12. A produção de serapilheira na área de vegetação natural corresponde a média citada por Brown \& Lugo (1982) para florestas tropicais e subtropicais que segundo os autores pode variar de 1 a 15,3 tha-1.ano-1. 
A produção de serapilheira se mostrou diferente a nível de 5\% de significância entre os ecossistemas ao longo do ano. O ecossistema que apresentou a menor produção anual de serapilheira foi o plantio antigo (E. saligna), sendo a maior produção encontrada no plantio de recente ( $E$. grandis). A diferença encontrada na produção de serapilheira entre os plantios antigo e recente pode estar relacionada, não somente a diferença de idade entre os povoamentos e as características químicas dos solo, mas também aos fatores relacionados como a espécie, uma vez que segundo Silva et al. (1983), o E. grandis se mostra mais eficiente que E. saligna na utilização de alguns nutrientes, como por exemplo o P. A produção encontrada para o plantio antigo de $E$. saligna, é comparável aos valores mencionados por Poggiani (1985) para um plantio de E. saligna, entre 10 e 13 anos de idade localizado na região de Piracicaba, que foi de 4,5 t.ha $^{-1} \cdot$ ano $^{-1}$. Turney \& Lambert (1983), registraram o mesmo valor de deposição anual de serapilheira $\left(4.5\right.$ t.ha $^{-1} \cdot$ ano $\left.^{-1}\right)$ em um povoamento de Eucalyptus grandis com 27 anos de idade na Austrália.

A densidade de plantio pode ser um outro fator a alterar a produção de serapilheira, pois os plantios apresentam espaçamento entre árvores diferente (4,0 $\mathrm{m} \mathrm{X}$ 4,0 m para o plantio de E. saligna e $1,8 \mathrm{~m} \mathrm{X} \mathrm{3,0} \mathrm{m} \mathrm{para} \mathrm{o} \mathrm{plantio} \mathrm{de} E$. grandis) o que causa diferenças de densidade arbórea. Além disso, o povoamento de E. saligna apresentava varias falhas nas linhas de plantio.

Outro fator que influencia a produção de serapilheira é a aplicação de fertilizantes. Madeira et al. (1983), testando a influência da adubação de eucalipto sobre a produção de serapilheira, verificou que os plantios adubados produzem mais serapilheira e que o aumento na produção de serapilheira ocorre nos períodos de máximo crescimento. 


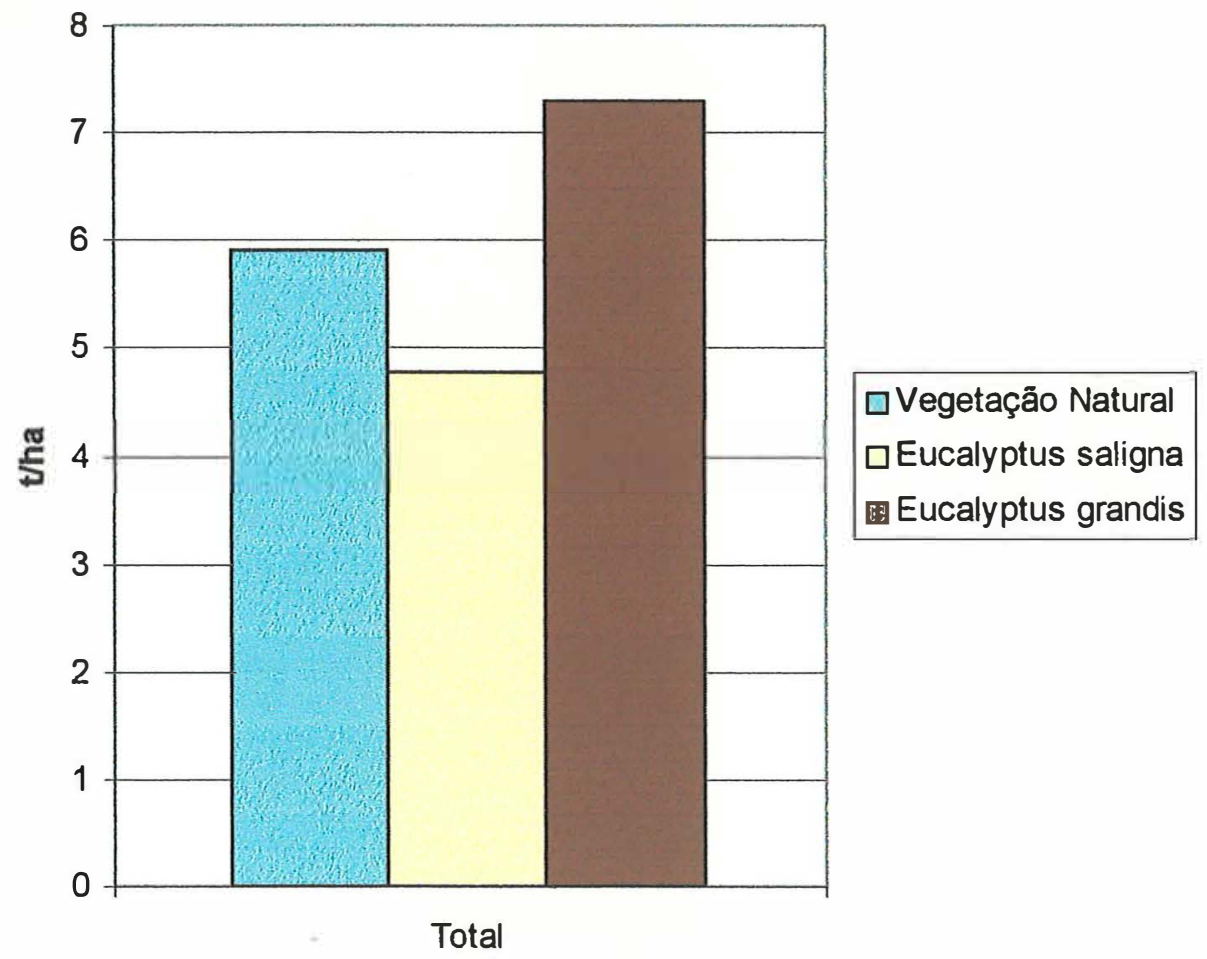

Figura 12. Produção anual de serapilheira em área de vegetação natural (cerradão), plantio de Eucalyptus grandis (plantio recente) e plantio de Eucalyptus saligna (plantio antigo) .

Neste experimento, a vegetação que produziu as maiores quantidade de serapilheira foi o E. grandis, que recebeu adubação.

A produção de serapilheira na área de vegetação nativa apresenta-se dentro dos valores encontrados por Peres (1983) que variaram de 2,1 t.ha ${ }^{-1} . \mathrm{ano}^{-1}$ para áreas de cerrado à 7,8 th.ha ${ }^{-1}$.ano ${ }^{-1}$ para áreas de cerradão, estando porém muito acima do que encontrou Mafra (1996) para uma área de campo cerrado na região de Botucatu ( 2,2 t.ha ${ }^{-1} \cdot$ ano $^{-1}$ ). Pompéia (1989) encontrou uma produção de 3,0 t.ha ${ }^{-1}$.ano ${ }^{-1}$ para uma área 
de cerrado no município de Mogi-Guaçu, e Delitti (1984), encontrou uma produção de serapilheira de 3,2 t.ha ${ }^{-1}$.ano ${ }^{-1}$ para a área de campo cerrado e de 5,9 th.ha $^{-1}$.ano ${ }^{-1}$ para um plantio de Eucalyptus spp na mesma região.

O fato da área de vegetação natural, apresentar valores de produção de serapilheira acima dos encontrados em outras áreas de cerrado e se aproximando dos valores encontrados para áreas de cerradão não perturbadas, pode estar relacionado com a degradabilidade do local, visto que além da área se encontrar em processo de regeneraçãoe se encontra também infestada por lianas, que adicionam elevadas quantidades de folhas ao solo.

Schlittler et al. (1993a) observaram uma correlação positiva entre o grau de perturbação do local e a quantidade de serrapilheira produzida pela presença das lianas nas copas das árvores.

Pagano (1989a) estudando a produção de folhedo em mata mesófila do Estado de São Paulo concluiu que as lianas são provavelmente responsáveis em grande parte pela alta produção de folhedo, pois estas apresentam uma maior produção foliar. Hegarty (1992) observou que a contribuição das lianas na produção de serapilheira foi em torno de 15 vezes maior que a das árvores.

Portanto, diferentes valores encontrados na serapilheira produzida devem estar estreitamente relacionadas com a maior ou menor ocorrência de lianas na área, sendo que este fato dependente do grau de perturbação da área (Pagano, 1989a; Schilitter, 1993a)

As áreas em estudo apresentaram sazonalidade na produção de serapilheira (Figura 13), sendo que as áreas de eucalipto apresentaram padrões semelhantes de produção. A área de plantio de E. grandis (plantio recente) apresentou dois picos de produção de serapilheira, um nos meses de novembro/dezembro, que contribuiu com $31 \%$ do total de serapilheira produzida e outro nos meses de fevereiro-abril com 32,3\%. Os outros 7 meses do ano contribuíram com apenas $36,7 \%$ do total de serapilheira, 
sendo as menores produções verificadas nos meses de setembro e outubro com $2,0 \%$ e $2,9 \%$ respectivamente, que correspondem ao início da estação chuvosa. Um pico de produção de serapilheira menor que os anteriores foi observado nos meses de julho e agosto. Os três picos de produção de serapilheira ocorreram nos meses em que houve diminuição na precipitação.

No talhão do plantio antigo, ocorreu um único pico de produção nos meses de novembro/dezembro, coincidindo com a diminuição na quantidade de precipitação. Estes dois meses concentraram 50\% da serapilheira total produzida em 12 meses. Nos meses seguintes a produção se manteve basicamente constante, sendo a menor produção observada no mês de setembro $(2,86 \%)$. Os picos de maior e menor queda de folhas dos plantios de E. grandis e E. saligna são coincidentes.

A área de vegetação nativa apresentou as maiores produções de serapilheira entre os meses de julho/novembro, que foram os meses que apresentaram as menores precipitações. A serapilheira produzida neste período correspondeu à $62,5 \%$ do total produzido. Os restantes $37,5 \%$ da produção de serapilheira se distribuíram ao longo dos meses de dezembro-junho. A menor produção ocorreu no mês janeiro, correspondendo à apenas $3,2 \%$ do total (Tabela 11 ).

Mafra (1996) verificou que $35 \%$ da serapilheira produzida em uma área de campo cerrado no município de Botucatu se concentrou nos meses de agosto-setembro, que foram os mais secos, coincidindo com o ocorrido neste estudo, no qual a área de vegetação natural também apresentou uma produção maior nos meses de agosto/setembro correspondendo à $29,3 \%$ do total.

De maneira geral a queda de folhas na região tropical é contínua, mas apresentando um pico máximo na estação seca (Meguro et al., 1979; Golley, 1983).

O padrão de produção de serapilheira apresentado pela vegetação natural deste experimento se encontra de acordo com com o citado pelos autores. 


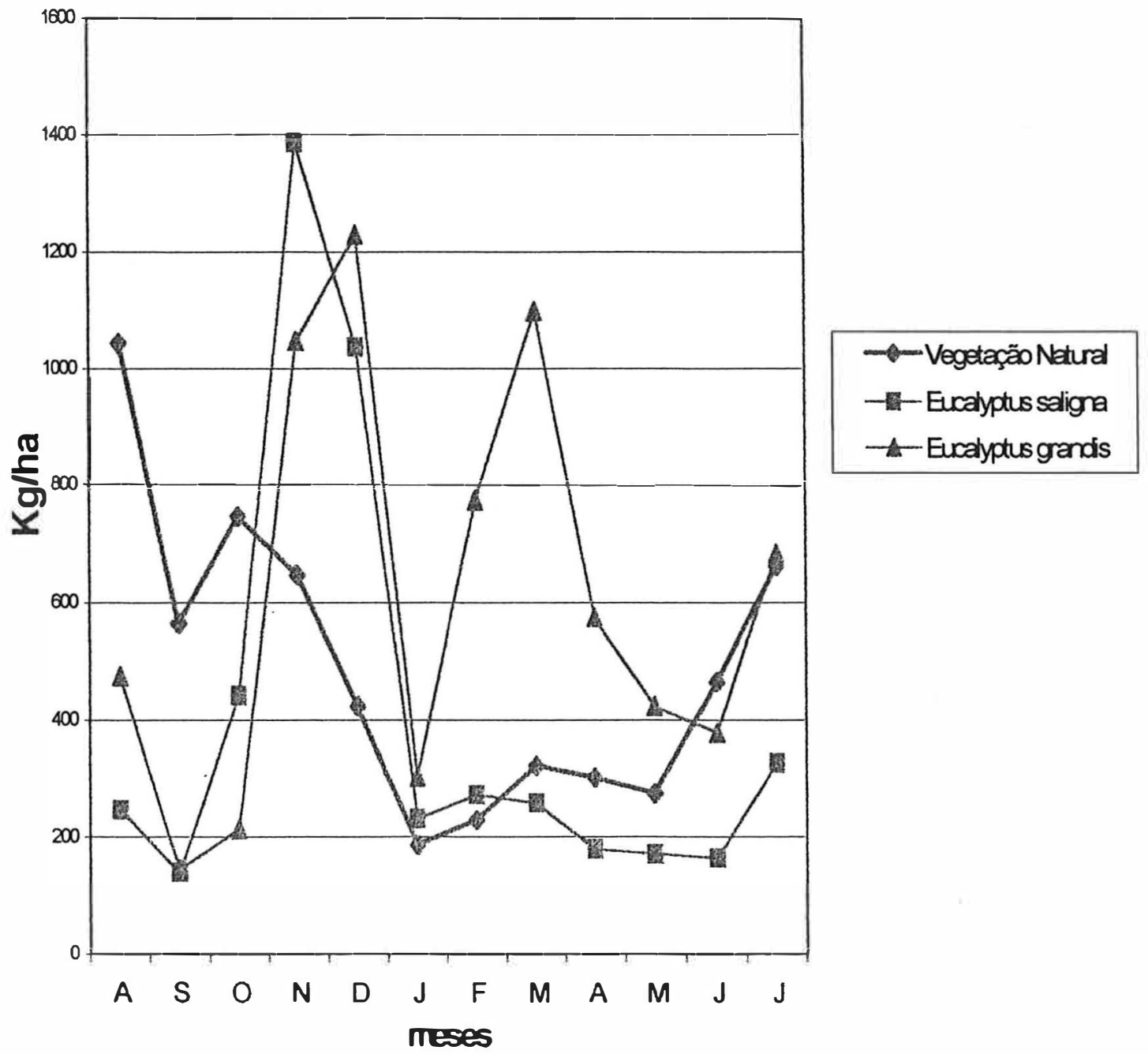

Figura 13 .Produção mensal de serapilheira em $\mathrm{Kg} / \mathrm{ha} \mathrm{em}$ área de vegetação natural, plantio de Eucalyptus saligna (plantio antigo) e plantio de Eucalyptus grandis (plantio recente), no município de Itatinga, (SP), durante o periodo de agostp de 1996 e julho de 1997. 
Tabela 11. Distribuição da produção de serapilheira em área de vegetação natural, plantio de Eucalyptus saligna (plantio antigo) e plantio de Eucalyptus grandis (plantio recente), no município de Itatinga, (SP).

\begin{tabular}{cccc}
\hline Meses & Vegetação Natural & E. saligna & E. grandis \\
\hline Ago-96 & $17,8 \%$ & $5,1 \%$ & $6,5 \%$ \\
Set-96 & $9,6 \%$ & $2,9 \%$ & $2,0 \%$ \\
Out-96 & $12,7 \%$ & $9,1 \%$ & $2,9 \%$ \\
Nov-96 & $11,1 \%$ & $28,6 \%$ & $14,3 \%$ \\
Dez-96 & $7,2 \%$ & $21,4 \%$ & $16,7 \%$ \\
Jan-97 & $3,2 \%$ & $4,8 \%$ & $4,1 \%$ \\
Fev-97 & $3,9 \%$ & $5,6 \%$ & $10,5 \%$ \\
Mar-97 & $5,5 \%$ & $5,3 \%$ & $15,0 \%$ \\
Abr-97 & $5,1 \%$ & $3,7 \%$ & $7,8 \%$ \\
Mai-97 & $4,7 \%$ & $3,5 \%$ & $5,8 \%$ \\
Jun-97 & $7,9 \%$ & $3,4 \%$ & $5,1 \%$ \\
Jul-97 & $11,3 \%$ & $6,7 \%$ & $9,3 \%$
\end{tabular}

A distribuição na produção de serapilheira pode representar uma estratégia dos ecossistemas para tornar mais eficiente a ciclagem de nutrientes, minimizando as perdas.

\subsubsection{Nutrientes deposistados transferidos ao solo via serapilheira}

A concentração dos nutrientes na serapilheira variou entre os meses. O teor médio dos nutrientes presentes na serapilheira se mostrou maior na área de vegetação 
natural. A serapilheira do plantio de $E$. grandis apresentou maiores teores de nutrientes depositados que do a serapilheira do E. saligna (tabela 12).

A quantidade de nutrientes devolvidos ao solo pela serapilheira variou entre os ecossistemas. $\mathrm{Na}$ área de vegetação natural, apesar da quantidade de serapilheira produzida ter sido menor do que no plantio de E. grandis, a quantidade de nutrientes devolvidos ao solo foi maior, para todos os nutrientes analisados.

O teor médio dos nutrientes presentes na serapilheira se mostrou maior na área de vegetação natural, sendo que os menores teores de nutrientes foram encontrados na serapilheira do plantio de E. saligna. A maior concentração de nutrientes presente no plantio de E. grandis deve-se possivelmente aos nutrientes adicionados ao solo pela adubação. Esta prática de manejo reflete não somente numa maior circulação dos nutrientes no sistema, mas também numa maior produção de biomassa.

A vegetação natural (cerrado) retornou ao solo através da serapilheira 150,1 Kg.ha ${ }^{-1} \cdot$ ano $^{-1}$ de N, 6,7 Kg.ha ${ }^{-1} \cdot$ ano $^{-1}$ de P, 29,1 Kg.ha ${ }^{-1} \cdot$ ano $^{-1}$ de K, 91,0 Kg.ha ${ }^{-}$ ${ }^{1}$.ano ${ }^{-1}$ de Ca e 23,2 Kg.ha ${ }^{-1}$.ano ${ }^{-1}$ de $\mathrm{Mg}$.

A área de plantio de E. saligna retornou 84,0 Kg.ha ${ }^{-1} \cdot$ ano $^{-1}$ de N, 2,6 Kg.ha${ }^{1}$.ano ${ }^{-1}$ de P, 12,6 Kg.ha ${ }^{-1}$.ano ${ }^{-1}$ de K, 43,1 Kg.ha ${ }^{-1}$.ano ${ }^{-1}$ de Ca e $12,5 \mathrm{Kg} \mathrm{ha}^{-1}$.ano ${ }^{-1}$ de $\mathrm{Mg}$.

A área de plantio de E. grandis retornou 93,3 Kg.ha ${ }^{-1} \cdot$ ano $^{-1}$ de N, 3,9 Kg.ha ${ }^{-1} \cdot$ ano $^{-}$ ${ }^{1}$ de P, 21,7 Kg.ha ${ }^{-1} \cdot$ ano $^{-1}$ de K, 54,2 Kg.ha ${ }^{-1} \cdot$ ano $^{-1}$ de Ca e 17,5 Kg.ha ${ }^{-1} \cdot a^{-1}$ de $\mathrm{Mg}$ (Tabela 13).

A área de vegetação natural retornou as maiores quantidade de $\mathrm{N}, \mathrm{K}, \mathrm{Ca}$ e $\mathrm{Mg}$ enquanto que o plantio de $E$. grandis retornou as maiores quantidade de P. A maior quantidade de $\mathrm{P}$ devolvida ao solo via serapilheira pelo E. grandis deve estar também relacionado com a sua maior eficiência de uso do P (Silva et al., 1983). 
Tabela 12. Concentração de nutrientes na serapilheira deposistada na área de vegetação natural, no talhão de E. saligna (plantio antigo) e de E. grandis (plantio recente).

\section{Teor de nutrientes $\left(\mathrm{g} \cdot \mathrm{Kg}^{-1}\right)$}

\begin{tabular}{lccccc}
\hline Ecossistemas & $\mathrm{N}$ & $\mathrm{P}$ & $\mathrm{K}$ & $\mathrm{Ca}$ & $\mathrm{Mg}$ \\
Vegetação Natural & 12,5 & 0,6 & 2,4 & 7,6 & 2,2 \\
E. saligna & 7,0 & 0,2 & 1,1 & 3,6 & 1,0 \\
E. grandis & 7,8 & 0,3 & 1,8 & 4,5 & 1,5 \\
\hline
\end{tabular}

Tabela 13. Quantidade de serapilheira produzida em área de vegetação natural, plantio de E. saligna (16 anos) e plantio de E. grandis (6 anos) em região de cerrado do Estado de São Paulo.

\begin{tabular}{ccccccc}
\hline \multirow{2}{*}{ Ecossistema } & Total depositado & \multicolumn{5}{c}{ Nutrientes transferidos em $\mathrm{Kg}^{-\mathrm{ha}^{-1}} \cdot$ ano $^{-1}$} \\
& t.ha-1.ano-1 & $\mathrm{N}$ & $\mathrm{P}$ & $\mathrm{K}$ & $\mathrm{Ca}$ & $\mathrm{Mg}$ \\
\hline Vegetação natural & 5,9 & 150,1 & 6,7 & 29,1 & 91,0 & 23,2 \\
Eucalyptus saligna & 4,8 & 84,0 & 2,6 & 12,6 & 43,1 & 12,5 \\
Eucalyptus grandis & 7,3 & 93,3 & 3,9 & 21,7 & 54,2 & 17,5 \\
\hline
\end{tabular}




\subsection{Serapilheira acumulada}

\subsubsection{Quantidade de serapilheira acumulada sobre o solo}

As quantidades de serapilheira acumuladas sobre o solo apresentaram diferenças significativas entre os ecossistemas. A área que apresentou a maior quantidade de serapilheira acumulada foi o plantio de Eucalyptus grandis (plantio recente), com 23,9 t.ha-1, seguido do plantio antigo $\cdot \operatorname{com} 17,7$ th.ha $^{-1}$ e da área com vegetação natural que apresentou 11,0 t.ha ${ }^{-1}$, como mostrado na Tabela 14 .

O acúmulo de material orgânico não decomposto sobre o solo em áreas reflorestadas com eucalipto pode ser atribuído a composição química da serapilheira e em especial a sua alta relação $\mathrm{C} / \mathrm{N}$ e a presença de componentes com ação antibacteriana (Della Bruna et al. , 1991). A quantidade de serapilheira acumulada em uma área de mata mesófila semi-decídua segundo Schlittler et al. (1993b), foi de 7,4 tha ${ }^{-1}$

Gama-Rodrigues et al. (1997) estudando em solos sob eucalipto encontrou que a manta orgânica sobre o solo foi de $14,3 \cdot$ ha $^{-1}$. ano ${ }^{-1}$ com um teor de $\mathrm{N}$ de 10,3 g.Kg-1 para a área com eucalipto.

Tabela 14. Estoque de serapilheira acumulada sobre o solo nos ecossistemas de vegetação natural, Eucalypus saligna com 16 anos e Eucalyptus grandis com 6 anos.

\begin{tabular}{cc}
\hline Ecossistema & Serapilheira acumulada sobre o solo em t.ha ${ }^{-1}$ \\
\hline Vegetação Natural & 11,0 \\
Eucalyptus saligna & 17,7 \\
Eucalyptus grandis & 23,9 \\
\hline
\end{tabular}




\subsubsection{Nutrientes armazenados na serapilheira acumulada}

As concentrações dos nutrientes nas serapilheiras estocadas sobre o solos das três áreas se encontram na Tabela 15.

Dentre os nutrientes estudados os que mais diferiram entre os ecossistemas foram o $\mathrm{N}\left(10,83 \mathrm{~g} \cdot \mathrm{Kg}^{-1}\right.$ na vegetação natural, $8,30 \mathrm{~g} \cdot \mathrm{Kg}^{-1}$ no plantio antigo e $3,18 \mathrm{~g} \cdot \mathrm{Kg}^{-1}$ no plantio recente) e o $\mathrm{K}\left(0,53 \mathrm{~g} \cdot \mathrm{Kg}^{-1}\right.$ na vegetação natural. $0,33 \mathrm{~g} \cdot \mathrm{Kg}^{-1}$ no plantio antigo e $0,28 \mathrm{~g} \cdot \mathrm{Kg}^{-1}$ no plantio recente). A serapilheira da vegetação natural foi a que apresentou os maiores valores para todos os nutrientes, com exceção do $\mathrm{Ca}$, cujo o maior teor foi encontrado na área de plantio de $E$. saligna (plantio antigo). As maiores variações na concentração de nutrientes ocorreram na vegetação natural. Isto se deve a grande diversidade de material presentes na serapilheira, uma vez composição florística da área em estudo apresenta grande variabilidade espacial.

Tabela 15. Concentração nutrientes estocados na serapilheira depositada sobre o solo em área de vegetação natural, plantio de Eucalyptus saligna (antigo) e plantio de Eucalyptus grandis (recente) em g. $\mathrm{Kg}^{-1}$.

\begin{tabular}{lccccc}
\hline \multicolumn{1}{c}{ Ecossistemas } & $\mathbf{N}$ & $\mathbf{P}$ & $\mathbf{K}$ & $\mathbf{C a}$ & $\mathbf{M g}$ \\
\hline Vegetação natural & 10,8 & 0,3 & 0,5 & 3,1 & 0,9 \\
E. saligna & 8,30 & 0,1 & 0,3 & 3,4 & 0,8 \\
E. grandis & 6,2 & 0,3 & 0,3 & 2,8 & 0,7 \\
\hline
\end{tabular}


Os nutrientes estocados na serapilheira sobre o solo (Tabela 16) que mais diferiram entre os ecossistemas foram o $\mathrm{P}$ e o $\mathrm{Ca}$, sendo o plantio de $E$. grandis de 6 anos o que apresentou as maiores quantidades destes nutrientes. Na vegetação natural a quantidade de $\mathrm{Ca}$ foi a menor dentre os três ecossistemas, estando o plantio de $E$. saligna com quantidade de $\mathrm{Ca}$ bastante próximas ao do plantio de $E$. grandis. $\mathrm{O} \mathrm{N}$ e o $\mathrm{K}$ foram os nutrientes que menos diferiram entre as áreas de estudo.

Apesar da quantidade de serapilheira acumulada sobre os solo ter sido maior nas área de Eucalyptus spp que na área de vegetação natural, o teor de alguns nutrientes foi praticamente igual para as três áreas, como N, e o K . Delitti (1984) verificou o mesmo quando estudou uma área de plantio de Eucalyptus spp e uma de campo cerrado, no estado de São Paulo.

Tabela 16. Nutrientes estocados na serapilheira depositada sobre o solo em uma área de vegetação natural, um plantio de Eucalyptus saligna (antigo), e em um plantio de Eucalyptus grandis (recente) em Kg.ha ${ }^{-1}$.

\begin{tabular}{cccccc}
\hline Ecossistemas & $\mathrm{N}$ & $\mathrm{P}$ & $\mathrm{K}$ & $\mathrm{Ca}$ & $\mathrm{Mg}$ \\
\hline Vegetação natural & 118,9 & 3,3 & 5,8 & 34,0 & 10,4 \\
Eucalyptus saligna & 146,7 & 2,2 & 5,7 & 60,1 & 14,1 \\
Eucalyptus grandis & 147,6 & 6,6 & 6,6 & 66,9 & 16,7 \\
\hline
\end{tabular}


A quantidade total de macronutrientes armazenados na serapilheira sobre o solo foi de $172,38 \mathrm{Kg} \mathrm{ha}^{-1}$ para a área de vegetação natural, $244,49 \mathrm{Kg} \cdot \mathrm{ha}^{-1}$ para a área plantada com E. grandis e de $228,83 \mathrm{Kg} \cdot \mathrm{ha}^{-1}$ para a área plantada com E. saligna.

O nitrogênio, dentre os nutrientes analisados, é o elemento que apresenta as maiores quantidade acumuladas na serapilheira dos três ecossistemas. No plantio de E.grandis a quantidade acumulada foi de $148 \mathrm{Kg} \mathrm{ha}^{-1}$, no plantio de E. saligna 147 Kg.ha ${ }^{-1}$ e na vegetação natural $119 \mathrm{Kg} \cdot \mathrm{ha}^{-1}$. A aplicação de fertilizantes em áreas de plantio de eucalipto apresentam um aumento na concentração de $\mathrm{N}$ e $\mathrm{P}$ na serapilheira, resultando num decréscimo na relação $\mathrm{C}: \mathrm{N}$, que pode facilitar a decomposição nestas áreas (Madeira et al., 1983). 


\section{CONSIDERAÇÕES GERAIS E CONCLUSÕES}

A biomassa alocada na vegetação e na serapilheira do plantio de E. grandis (plantio recente) e de E. saligna (plantio antigo) se mostraram semelhantes, e maiores em relação à área de vegetação natural (cerradão) (Figura 14).

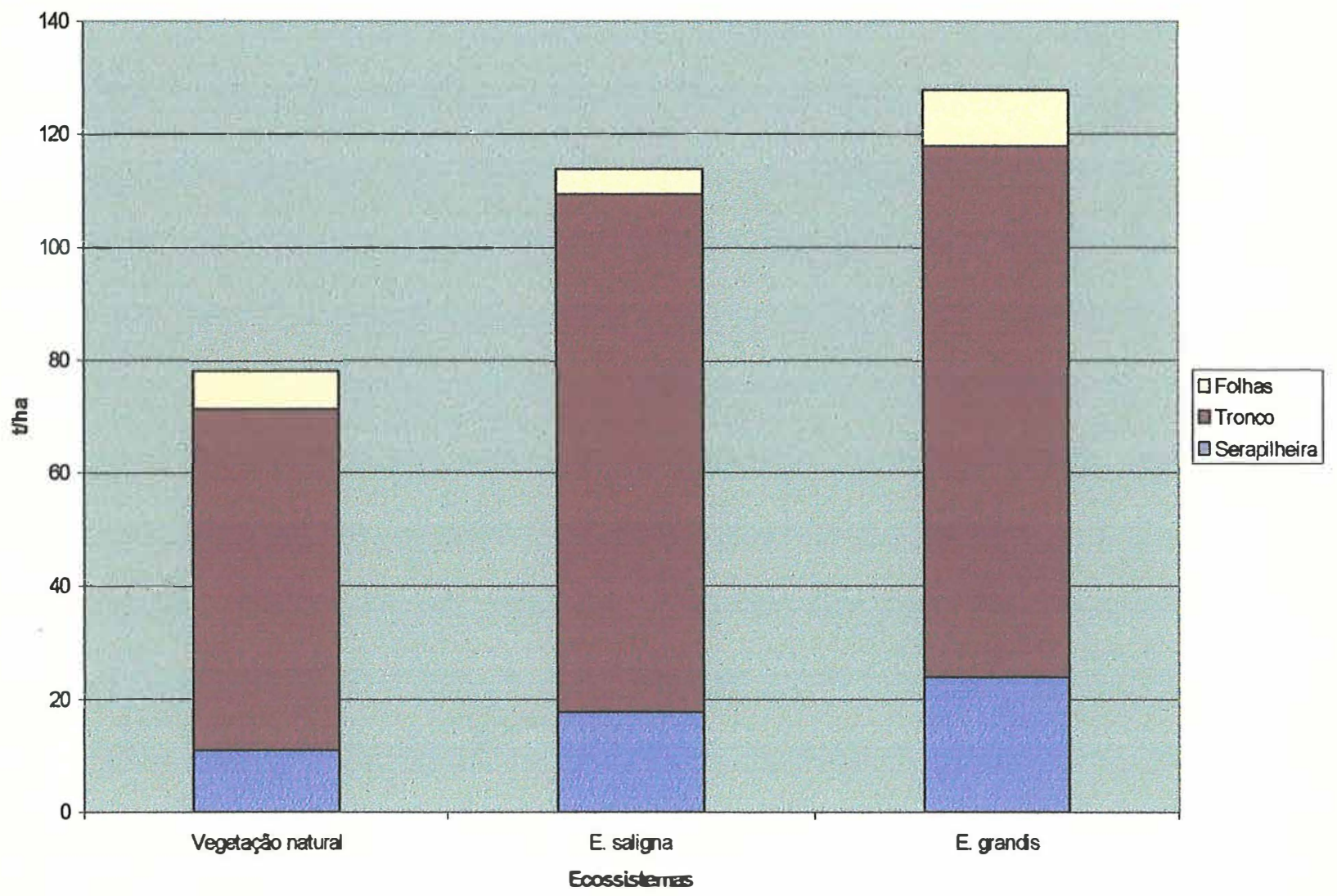

Figura 14. Distribuição da biomassa na serapilheira, tronco e folhas nos ecossistemas de vegetação natural, plantio de E. saligna e E. grandis 
O plantio de E. grandis alocou uma maior quantidade de biomassa nas folhas que o plantio de E. saligna. O grande acúmulo de serapilheira encontrado na área de plantio de E. saligna pode ser atribuído a decomposição mais lenta desta devido a baixa concentração de nutrientes.

Os maiores estoques totais de nutrientes foram encontrados na área de plantio de E. grandis (plantio recente) (Figura 15), excetuando-se o $\mathrm{Mg}$ que se apresentou em maior quantidade na área de vegetação natural. $O$ acúmulo de nutrientes na área de plantio de $E$. grandis é devido a aplicação de fertilizantes na área, que proporcionaram uma maior disponibilidade de nutrientes para a vegetação.

A área de plantio de E. saligna (plantio antigo) (Figura 13) apresentou os menores estoques totais de $\mathrm{N}, \mathrm{P}, \mathrm{K}$ e $\mathrm{Ca}$ em todos os compartimentos estudados (solo, serapilheira, vegetação). $\mathrm{O} N$ é o nutriente mais afetado pelo sistema de cultivo empregado nos talhões de E. saligna. O aparente esgotamento do solo na área sob plantio de E.saligna pode ser atribuido a grande quantidade de nutrientes exportados da área nos diversos cortes de madeira realizados.

Quando se analisa o compartimento solo, encontramos os maiores estoques de de $\mathrm{N}$ e K na área de vegetação natural (Figura 14), de $\mathrm{P}$ e Ca na área de plantio E. grandis e $\mathrm{Mg}$ na área de plantio de $E$. saligna. Os maiores estoques de $\mathrm{N}$ devem ser resultado da função da leguminosas em aumentar o nitrogênio disponível no solo da vegetação natural.

$\mathrm{Na}$ área de vegetação natural e no plantio de $E$. saligna, a única fonte de entrada de nutrientes ao solo foi devido a precipitação.

A quantidade de nutrientes adicionados pela precipitação ao longo de 16 anos na área de plantio de E. saligna, tomando-se como base os valores obtidos por Mafra (1996) podem ser estimados em: $248 \mathrm{Kg} \cdot \mathrm{ha}^{-1}$ de N, $45 \mathrm{Kg} \mathrm{ha}^{-1}$ de P, $86 \mathrm{Kg}^{-h^{-1}}{ }^{-1}$ de K, $208 \mathrm{Kg} \cdot \mathrm{ha}^{-1}$ de Ca e $39 \mathrm{Kg} \mathrm{ha}^{-1}$ de Mg. 
Este fato sugere que a adição nutrientes via precipitação poderia ser, até certo ponto, suficiente para os plantios de eucaliptos desde que as rotações fossem prolongadas.

Através disto podemos concluir que uma maneira de minimizarmos o impacto causado pelas plantações homogêneas sobre a fertilidade do solo na região de cerrado seria através da adoção de práticas de manejo que permitam uma utilização mais eficiente dos nutrientes presentes no solo. Dentre elas pode-se citar: o uso de espécies melhoradas, mais eficiente no uso dos nutrientes e adaptadas para cada área; a aplicação de fertilizantes nas fases inicias de crescimento do plantio; desbastes periódicos dos ramos que não apresentam valor comercial, diminuindo a quantidade de nutrientes imobilizada na vegetação; a manutenção de todo o material vegetal sobre o solo; adotadas rotações mais longas, que permitiriam um maior equilíbrio entre a quantidade de nutrientes que entram no sistema pela precipitação e a quantidade que será exportada pela colheita 


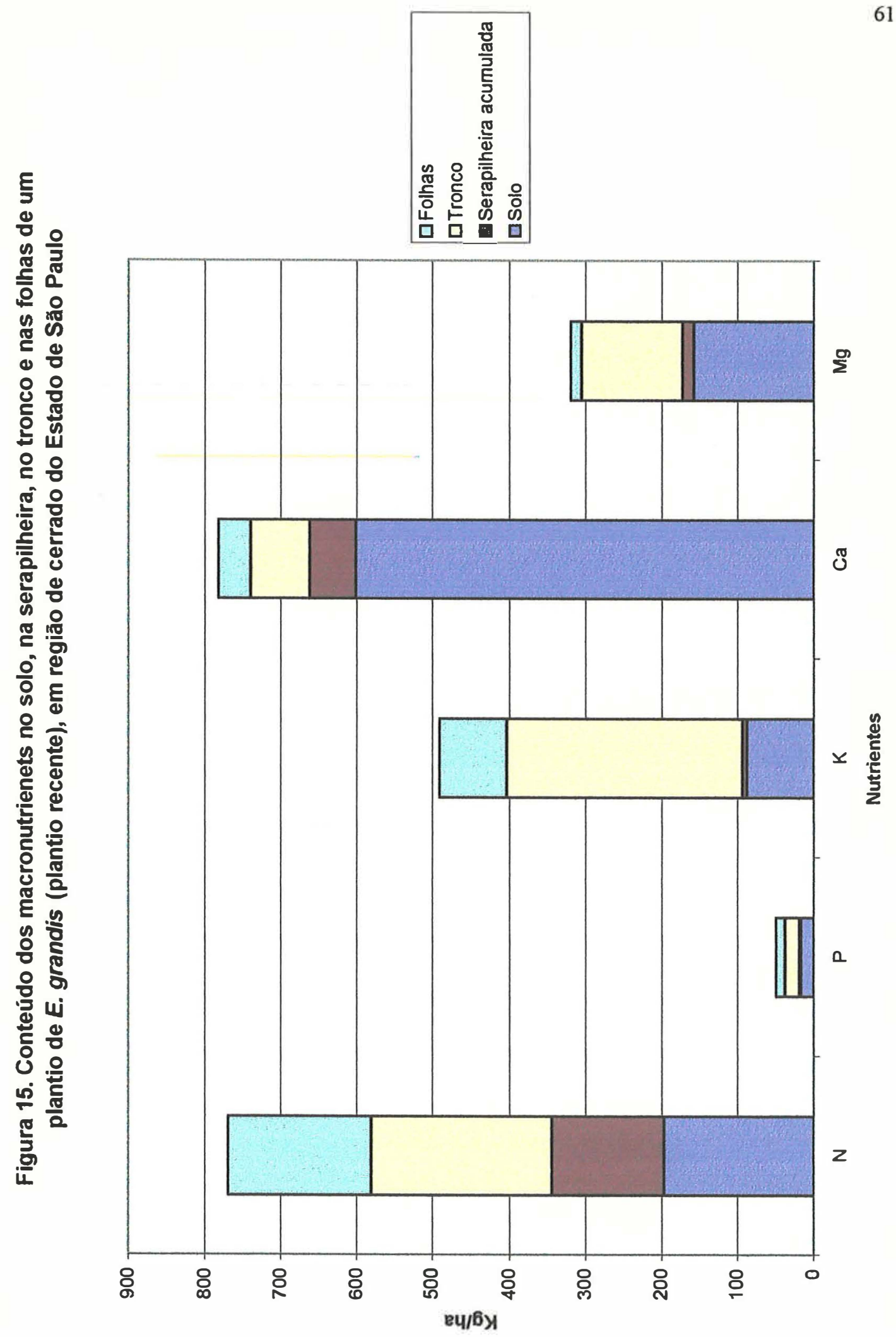




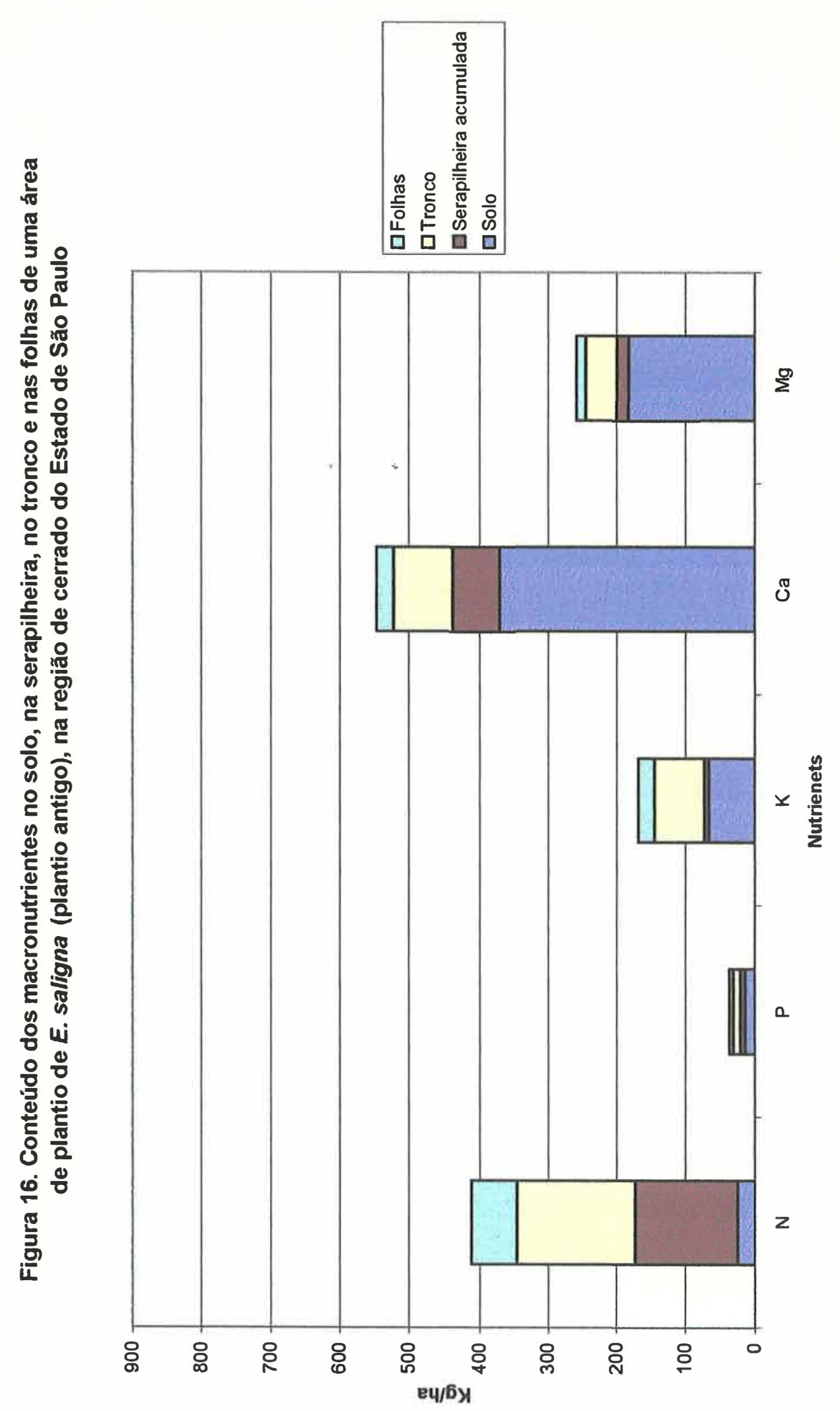




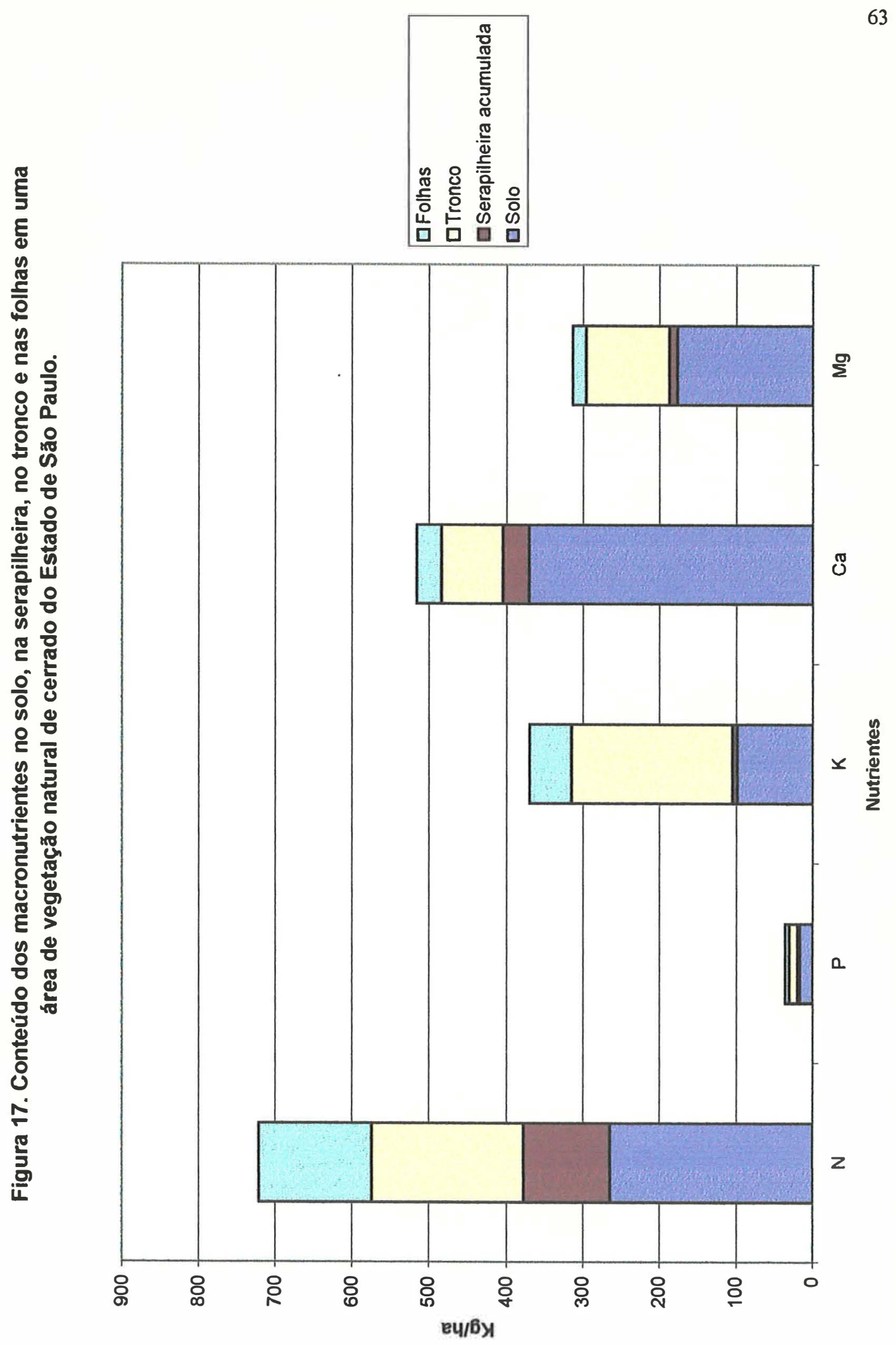




\section{REFERÊNCIAS BIBLIOGRAFICAS}

ALVIM, P. de T. Teoria sobre a formação dos campos cerrados. Revista Brasileira de Geografia. v.16, n.4, p. 496-498. 1954.

AOKI, H. \& SANTOS, J.R. dos. Fatores ambientais dos cerrados e imagens orbitais. Boletim Técnico do Instituto Florestal, São Paulo. n.31, set., p. 69, 1979.

BELLOTE, A. F. J.; FERREIRA, C.A.. Nutrientes minerais e crescimento de árvores adubadas de Eucalyptus grandis, na região do cerrado, no estado de São Paulo. Boletim de Pesquisa Florestal, Colombo, 26-27:jan-dez, 1993

BRAGA, F.A.; VALE, F.R. \& MUNIZ, J.A. Movimentação de nutrientes no solo, crescimento e nutrição mineral do eucalipto, em função de doses de gesso e níveis de irrigação. Revista Brasileira de Ciência do Solo. v.19, set./dez., p. 69-77, 1995.

BRAY, J.R.; GORHAM, E. Litter productions in forest of the word. Adv. Ecol. Res., v.2, p101-157, 1964.

BROWN, S.; LUGO, A.E. The storage and production of organic matter in tropical forest and their role in the global carbon cycle. Biotropica, v.14, n.3, p.161-187, 1982. 
BROWN, S.; ANDERSON, J.M.; WOOMER, P.L.; SWIFT, M.J. BARRIOS, E. Soil biological processes in tropical ecosystems. in: The biological management of tropical soil fertility. 1994. 15-46p.

BRAY, J. R. \& GORHAM, E. Litter production in forests of the world. Adv. Ecol. Rev. v.2, p.101-57, 1964

CAVASSAN, O. Florística e Fitossociologia da Vegetação Lenhosa de um Hectare de Cerrado no Parque Ecológico Municipal de Bauru (SP). Campinas, 1990. 206 p. Tese (Doutorado) - IB/UNICAMP.

CESAR, O.; PAGANO, S. N.; LEITÃO FILHO, H. F.; SILVA, O. A.; MARINIS, G.; SHEPHERD, G. J.. Estrutura Fitossociológica do Estrato Arbóreo de uma Área de Vegetação de Cerrado no Município de Corumbataí (Estado de São Paulo). Naturalia, São Paulo, v.13, p.91-102, 1988

COUTINHO, L.M. O conceito de cerrado. Revista Brasileira de Botânica, São Paulo. V.1, p.17-24, 1979

COUTO, H.T.Z. Equações de volume e peso para estimar biomassa de Eucalyptus. In: SIMPÓSIO ENERGIA E BIOMASSA FLORESTAL. p.38-58. 1983

DELITTI, W. B. C. Ciclagem de nutrientes minerais em matas ciliares. In: SIMPÓSIO SOBRE MATA CILIAR. São Paulo, 1983. Anais. São Paulo: Fundação Cargill, 1983. 
DELITTI, W. B. C. Aspectos comparativos da ciclagem de nutrientes minerais na mata ciliar no campo cerrado e na floresta implantada de Pinus elliotti Englm. var. elliotti (Mogi Guaçu, S. P.). São Paulo, 1984. 298 p. Tese (Doutorado) - Institudo de Biociências da Universidade de São Paulo/USP.

DELLA BRUNA, E.; BORGES, A.C.; FERNANDES, B.; BARROS, N.F.; MUCHOVES, R.M.C. Atividade da microbiota de solos adicionados de serapilheira de eucalipto e de nutrientes. Revista Brasileira de Ciência do Solo. v.13, n. 1, p.1520. 1991

FONSECA, S.,BARROS, N.F., NOVAIS, R.F., LEAL, P.G. L., LOURES, E.G., MOURA FILHO, W. Alterações em um latossolo sob eucalipto, mata natural e pastagem. II. Propriedades orgânicas e microbiológicas. Revista Árvore. Viçosa, v. 17, n.3, p.289-302, 1993.

GOLLEY, F.B. Tropical rain forest ecosystems: structure and function. Amsterdan: Elsevier, 1983. 392 p.

HEGARTY, E.E. Leaf litter production by lianes and trees in a sub-tropical Australian rais forest. Journal of Tropical Ecoly v.7, p.201-214, 1991.

HUNTER, I.R.; SMITH, W. Principles of forest fertilisation - illustrated by New Zealand experience. Fertilizer Research v.43, n. 1-3, p. 21-29, 1996.

IBGE. Instituto Brasileiro de Geografia e Estatística. Mapa de Vegetação do Brasil. Escala 1:5.000.000. IBGE, Rio de Janeiro, 1993 
JORDAN, C. F. Nutrient cycling in tropical forest ecossystms. New York; John Wiley \& Sons, 1985. 179p

KER, J. C.; PERERA, N. R.; CARVALHO JR., W.; CARVALHO FILHO;A. Cerrados: Solos, Aptidão e Potencialidade Agrícola. Anais do Simpósio sobre Manejo e Conservação do Solo no Cerrado. Campinas, SP, Fundação Cargill, 1992.

LANDSBERG, J.J. \& GOWER,S.T. Applications of Physiological Ecology to Forest Management In: Physiological ecology of forest production, London: Academic Press, 1986. 216p.

LAS SALAS, G. Aspectos sobre la reforestacion y el balance nutricional del sitio en los tropicos. In: FLORESTAS PLANTADAS NOS NEOTRÓPICOS COMO FONTE DE ENERGIA.Viçosa, 1983. Anais. Viçosa, 1983.

MADEIRA, M; ARAÚJO, M.C.; PEREIRA, J.S.; HUTTL, R.F.; NILSSON, L.O.; JOHANSSON, U.T. Effects of water and nutrient supply on amount and on nutrient concentration of litterfall and forest floor litter in Eucalyptus globulus plantations. Plant and Soil. v.168-169, p. 287-295. 1995

MAFRA, A.L. Balanço de nutrientes em um sistema agroflorestal no cerrado de Botucatu, SP. .ESALQ/USP Piracicaba, 1996. 65 p. Tese (Mestrado). Escola Superior de Agricultura "Luiz de Queiroz", Universidade de São Paulo.

MEGURO, M.; VINUIZA, G.N.; DELITTI, W.B.C. Ciclagem de nutrientes na mata mesófila secundária I- Produção e conteúdo de nutrientes minerais no folhedo. Botetim de Botânica da Universidade de São Paulo, v.7, p.11-31, 1979. 
MELO,J.T.; MOURA,V.P.G.; RESCK,D.V.S. Acúmulo de serrapilheira e de nutrientes por Eucalyptus grandis Hill ex Maiden e Eucalyptus camaldulensis Dehnh em área de cerrado.In: CONGRESSO FLORESTAL BRASILEIRO, 7, Curitiba 1993.

Anais. São Paulo: SBS/SBEF. v.1, p.217-20. 1993.

NASCIMENTO, E. J.; MOURA FILHO, W.; COSTA, L. M; CRUA, J. C.; REGAZZI, A. J. Dinâmica da matéria orgânica em um latossolo vermelho-escuro distrófico, fase cerrado, submetido a diferentes sistemas de manejo. Revista Ceres. v.38, n.220, p.513-521. 1991.

NASCIMENTO, V.M; ALMENDROS, G.; FERNANDES, F.M. Evolution patterns of the soil organic matter in some agricultural systems in the Brazilian "Cerrado" region. European Journal of Soil Biology. v. 29, n.3-4, p. 177-182. 1993.

PAGANO, S.N. Produção de folhedo em mata mesófila semidecídua no município de Rio Claro, SP. Revista Brasileira de Biologia, V.49, n.3, p.633-639. 1989a

PAGANO, S.N. Nutrientes minerais no folhedo produzido em mata mesófila semidecídua no município de Rio Claro, SP. Revista Brasileira de Biologia, V.49, n.3, p.641-647. 1989b

PAGANO, S.N.; CESAR, O.; LEITÃO-FILHO, H.F. Composição florística do estrato arbustivo-arbóreo da vegetação de cerrado da área de proteção ambiental (APA) de Corumbataí - Estado de São Paulo. Revista Brasileira de Biologia, V.49, n. 1, p.3748. 1989a 
PAGANO, S.N.; CESAR, O.; LEITÃO-FILHO, H.F. Estrutura fitossociológica do estrato arbustivo-arbóreo da vegetação de cerrado da área de proteção ambiental (APA) de Corumbataí - Estado de S,o Paulo. Revista Brasileira de Biologia, V.49, n. 1, p.49-59. $1989 \mathrm{~b}$

PEREIRA, J.; PERES, J.R.R. Manejo da matéria orgânica. In: GOEDERT, W.J. Solos dos cerrados: tecnologias e estratégias de manejo. São Paulo: Nobel; Brasilia: EMBRAPA/CPAC, 1985. Cap.10, p.261-284.

PERES, J.R.R.; SUEHT, A.R.; VARGAS, M.A.T; DROZDOWICZ, A. Litter production in areas of brazilian cerrados. Pesquisa Agropecuária Brasileira, v.18, n. 9, p. $1037-1043,1983$

PESSOTTI, F. E. S. Levantamento detalhado dos solos do Horto de Itatinga. Piracicaba, ESALQ/ Departamento de Ciências Florestais. 1994. 105p

POGGIANI, F. Ciclagem de nutrientes e manutenção da produtividade da floresta plantada. In: FUNDAÇÃO CENTRO TECNOLÓGICO DE MINAS GERAIS. Gaseificação de Madeira e carvão vegetal. Belo Horizonte, CETEC, 1981, p.2633.

POGGIANI, F. Biomass and nutrient estimates removal in short rotation intensively cultured plantation of Eucalyptus grandis. In: FLORESTAS PLANTADAS NOS NEOTRÓPICOS COMO FONTE DE ENERGIA . Viçosa, 1983. Anais Viçosa, 1983.

POGGIANI, F. Ciclagem de nutrientes em ecossistemas de plantações florestais de Eucalyptus e Pinus. Implicações silviculturais. Piracicaba, São Paulo, 1985. 211 p. 
Tese (Livre-Docente) - Escola Superior de Agricultura "Luiz de Queiroz" , Universidade de São Paulo.

POGGIANI, F. Ciclagem de nutrientes e manutenção da produtividade da floresta plantada. In: GASEIFICAÇÃO DA MADEIRA E CARVÃO VEGETAL. Belo Horizonte, 1993. Fundação Centro Tecnológico de Minas Gerais. p. 35 - 44.

POGGIANI, F.; BRANCO, E.F. Workshop sobre monitoramento ambiental em áreas florestadas, 1, Piracicaba. Memória. Série Técnica IPEF, v.10, n.29, p.1-79, nov. 1996.

POGGIANI,F.; SCHUMACHER,M.V. Atmospheric inputs compared with nutrient removed by harvesting from Eucalyptus plantation: implications for sustainability. In: IUFRO CONFERENCE ON SILVICULTURE AND IMPROVEMENT OF EUCALYPTS, Salvador, 1997. Anais. Colombo: EMBRAPA/CNPF, 1997. v.4, p.68-74.

POMPÉIA, L.P. Aspectos da dinâmica dos nutrientes minerais em solo sob vegetação de campo-cerrado (Mogi-Guaçu-SP). 1989137 p. Dissertação (Mestrado) - Instituto de Biociências da Universidade de São Paulo - São Paulo

PRICHETT, W.L. Properties and management of forest soils. New York: John Wiley and Sons, 1987. 500p.

QUEIROZ NETO, J.P. Solos da região dos cerrados e suas interpretações. Revista Brasileira de Ciência do Solo, v.6, n. 1, p 11-2, 1982 
RAIJ, B.V.; QUAGGIO, J.A. Métodos de análise de solo para fins de fertilidade. Boletim técnico n. 81 Instituto Agronômico de Campinas, 1983, 31p.

RESCK, D.V.S. Manejo e conservação do solo em microbacias hidrográficas na região dos cerrados. Planaltina: EMBRAPA-CPAC, 1992. 17p. (EMBRAPA-CPAC. Documentos, 40$)$.

RIZZINI, D.T. Análise florística das savanas centrais. A flora do cerrado. In: SIMPÓSIO SOBRE CERRADO, São Paulo. Ed. USP, 1963. p. 125-177.

RIZZINI, D.T; COIMBRA FILHO, A.F. Ecossistemas brasileiros. Rio de Janeiro: Index, 1988. 200p.

SANTOS, H.P. \& TOMM, G.O. Estudo da fertilidade do solo sob quatro sistemas de rotação de culturas envolvendo trigo em plantio direto. Revista Brasileira de Ciência do Solo. v.20, n.3 p 407-414. 1996

SANTOS, J.C.F. Mobilização de cálcio e alumínio em solos ácidos por compostos orgânicos hidrossolúveis de resíduos vegetais. CENA/USP. Piracicaba, 1997. 72p. Tese (doutorado). Centro de Energia Nuclear na Agricultura - Universidade de S,o Paulo.

SARRUGE, J. R. \& HAAG, H. P.. Análise química em plantas. Piracicaba, ESALQ, 1974. 56p.

SCARDUA, F. P. Caracterização hidrológica de uma microbacia hidrográfica experimental da Estação Experimental de Ciências Florestais de Itatinga, 
ESALQ/USP. Piracicaba, 1994. 93p. Tese (Mestrado) - Escola Superior de Agricultura "Luiz de Queiroz", Universidade de São Paulo.

SCHLITTLER, F.H.M.; MARINIS, G. CESAR, O. Produção de serapilheira na floresta do Morro do Diabo, Pontal do Paranapanema - S.P. Naturalia, v.18, p. 135-148. 1993 a

SCHLITTLER, F.H.M.; MARINIS, G. CESAR, O. Decomposição da serapilheira produzida na floresta do Morro do Diabo (região do Pontal do Paranapanema, Estado de São Paulo). Naturalia, v.18, p. 149-156. 1993 b

SCHUMACHER, M.V. Aspectos da ciclagem de nutrientes e do microclima em talhões de Eucalyptus calmadulensis Dehnh, Eucalyptus grandis Hill ex Maiden e Eucalyptus torelliana F. Muell. , ESALQ/USP. Piracicaba, 1992. 87p. Tese (Mestrado) - Escola Superior de Agricultura "Luiz de Queiroz", Universidade de São Paulo.

SERRA FILHO,R. CHIARINI,J.V.; et al. Levantamento da cobertura natural e de reflorestamento no estado de São Paulo. Boletim Técnico do Instituto Florestal, São Paulo, n. 11, p. 1-56. 1974

SILVA ,H.D; POGGIANI, F.; COELHO, L.C. Eficiência de utilização de nutrientes em cinco espécies de Eucalyptus. Boletim de Pesquisa Florestal, v.6/7, p.1-8, 1983

SILVA, J.E.; LEMAINSKI, J. \& RESCK, D.V.S. Perdas de matéria orgânica e suas relações com a capacidade de troca catiónica em solos da regi,,o de Cerrados do Oeste baiano. Revista Brasileira de Ciência do Solo. v.18, set./dez., p. 542-543, 1994. 
SOARES, C.P.B.; PAULA NETO, F. de; SOUZA, A.L. de; LEITE, H.G. Modelos para estimar a parte aérea em um povoamento de Eucalyptus grandis na região de Viçosa, Minas Gerais. Revista Árvore, Viçosa, v.20, n.2, p. 179-189, 1996.

TOLEDO FILHO, D.V. Composição Florística e Estrutura Fitossociológica da Vegetação de Cerrado no Município de Luís António (SP). Campinas, 1984. 173 p. Tese (Mestrado) UNICAMP.

TURNER, J. \& LAMBERT, M.J. Nutrient cycling within a 27-year-old Eucalyptus grandis plantations in New South Wales. Forest Ecology and Management. V.6, n.2, p.155-168, 1983. 